\title{
Implementation and testing of a desert dust module in a regional climate model
}

\author{
A. S. Zakey ${ }^{1}$, F. Solmon ${ }^{2}$, and F. Giorgi ${ }^{2}$ \\ ${ }^{1}$ Department of Chemistry Atmospheric Science Goteborg University SE- 412, 96 Goteborg, Sweden \\ ${ }^{2}$ The Abdus Salam International center for Theoretical Physics, Physics of Weather and climate section, Strada Costiera 11, \\ 34100 Trieste, Italy
}

Received: 15 November 2005 - Published in Atmos. Chem. Phys. Discuss.: 10 March 2006

Revised: 17 July 2006 - Accepted: 12 September 2006 - Published: 19 October 2006

\begin{abstract}
In an effort to improve our understanding of aerosol impacts on climate, we implement a desert dust module within a regional climate model ( $\operatorname{Reg} C M)$. The dust module includes emission, transport, gravitational settling, wet and dry removal and calculations of dust optical properties. The coupled RegCM-dust model is used to simulate two dust episodes observed over the Sahara region (a northeastern Africa dust outbreak, and a west Africa-Atlantic dust outbreak observed during the SHADE "Saharan Dust Experiment"), as well as a three month simulation over an extended domain covering the Africa-Europe sector. Comparisons with satellite and local aerosol optical depth measurements shows that the model captures the main spatial (both horizontal and vertical) and temporal features of the dust distribution. The main model deficiency occurs in the representation of certain dynamical patterns observed during the SHADE case which is associated with an active easterly wave that contributed to the generation of the dust outbreak. The model appears suitable to conduct long term simulations of the effects of Saharan dust on African and European climate.
\end{abstract}

\section{Introduction}

Atmospheric aerosol direct and indirect radiative effects play an important role for climate and the environment, therefore it is important to include the description of aerosol processes in climate models (Penner et al., 2001). In particular, desert dust is the main aerosol component in many arid and semiarid regions of the world, such as the Sahara and Sahel in Africa or the desert regions of central Asia. Desert dust is emitted through suspension, saltation and creeping processes associated with wind erosion (Bagnold, 1941). Dust

Correspondence to: F. Solmon

(solmon@ictp.it) emission mostly occurs in episodic events determined by threshold near-surface wind conditions (Gillette and Hanson, 1989). The finer dust particles can be lifted up to high altitudes, where they are transported long distances from the source regions, often thousands of kilometers (Mahowald et al., 2002). As a result, the effects of desert dust can be felt not only locally but also in regions far from the sources.

A number of efforts have been made to simulate the desert dust cycle in climate models, particularly at the global scale (Joussaume, 1990; Cakmur et al., 2004, 2005; Miller et al., 2004, 2006; Zender et al., 2004; Luo et al., 2003). Fewer studies are available on the inclusion of dust processes in regional climate models (RCMs) (Gong et al., 2003; Song and Carmichael, 2001; Nickovic et al., 2001). Dust radiative effects on climate are likely to be especially important at the regional scale. Thus RCMs can be particularly useful tools to investigate the regional climatic effects of dust.

Based on these premises, we describe here the implementation and testing of a dust module within the regional climate modeling framework RegCM (Giorgi et al., 1993a, b; Giorgi and Mearns, 1999; and Pal et al., 2005). The model includes processes of dust emission by wind erosion, transport by resolvable scale winds, turbulent diffusion and deep convection, removal by wet and dry processes and gravitational settling. The dust particle size distribution is represented by size bins and the dust emission term includes the effects of both wind intensity and surface characteristics.

In this paper we test the dust model in three different simulations of dust generation over the Sahara region. The arid and semiarid regions of the African desert are major sources of mineral dust and thus play an important role in the global aerosol cycle (e.g., Mahowald et al., 2002; Sokolik et al., 1998). Dust lifted from the Sahara can be transported northward across the Mediterranean region up to central and northern Europe, or westward across the Atlantic ocean to occasionally reach the eastern coasts of the United States (Moulin et al., 1997).

Published by Copernicus GmbH on behalf of the European Geosciences Union. 
The first test simulation we consider is a dust episode which occurred on 13-16 March 1998, when a dust storm swept across northeastern Africa (through Algeria, Lybia, Sudan and Egypt) and reached the eastern Mediterranean and Middle East countries. For this case, the model simulation is validated with aerosol indices obtained from Total Ozone Mapping Spectrometer (TOMS) satellite maps. The second test case is a Western Sahara - Atlantic outbreak that occurred during 20-29 September 2000 between the coasts of West Africa and the Cabo Verde Islands. During this period the Saharan Dust Experiment (SHADE) was conducted using a combination of in-situ, photometer, lidar and satellite measurements (Tanré et al., 2003). The SHADE dataset offers a unique opportunity to validate different aspects of our aerosol model. The third simulation is for the period June-July-August (or JJA), 2000, and is validated against Multi-angle Imaging Spectro-radiometer (MISR) satellite data. This third test case provides a validation of the model for "climate mode" type experiments (i.e. experiments longer than the several day time scale characteristic of individual synoptic events), and is particularly relevant in view of our objective to use the coupled model for climate applications. This set of test experiments thus allows us to evaluate the model performance from the scale of individual episodic events to the long temporal scale.

Although the final goal of our model development effort is to simulate the climatic effects of aerosols, the dust calculated in the present simulations does not radiatively interact with the RegCM. To fully assess the climatic effects of aerosols requires long term multi-year simulations which are beyond the purpose of this paper. We also emphasize that the present modeling effort is placed within the broader effort of modeling natural and anthropogenic aerosols for regional climate applications initiated by Qian et al. (2001) and Solmon et al. (2006).

In Sect. 2 we first present a description of the dust module along with a brief description of RegCM and the three test cases. Results from the simulations are then validated using observations in Sect. 3, while Sect. 4 presents our summary and concluding remarks.

\section{Dust parameterization in the $\operatorname{RegCM}$}

\subsection{The RegCM model}

The RegCM has been developed for the last decade or so at the National Center for Atmospheric Research (NCAR) and later at the Abdus Salam International Centre for Theoretical Physics (ICTP) (Giorgi et al., 1993a, b; Giorgi and Mearns, 1999; Pal et al., 2005). It is a hydrostatic, sigma vertical coordinate model whose dynamics is essentially the same as the hydrostatic version of the mesoscale model MM5 (Grell et al., 1994). Typical horizontal resolutions for climate application range from 20 to $80 \mathrm{~km}$. Radiative transfer processes are from the NCAR global model CCM3 and are described by Kiehl et al. (1996). The boundary layer processes follow the non-local parameterization of Holtslag et al. (1990), while the scheme of Grell (1993) is used to describe moist convection and the parameterization of Pal et al. (2000) represents non-convective precipitation. Land surface processes are described via the Biosphere-Atmosphere Transfer Scheme (BATS, Dickinson et al., 1993). As described below, the BATS interface provides most of the variables used to couple the dust emission scheme. Over the years, the RegCM has been used for a wide range of applications (e.g. Giorgi and Mearns, 1999).

\subsection{Dust emission parameterization}

The representation of dust emission processes is a key element in a dust model and depends on the wind conditions, soil characteristics and particle size. Following Marticorena and Bergametti (1995) and Alfaro and Gomes (2001), here the dust emission calculation is based on parameterizations of soil aggregate saltation and sandblasting processes. The main steps in this calculation are: The specification of soil aggregate size distribution for each model grid cell, the calculation of a threshold friction velocity leading to erosion and saltation processes, the calculation of the horizontal saltating soil aggregate mass flux, and finally the calculation of the vertical transportable dust particle mass flux generated by the saltating aggregates. In relation to the BATS interface, these parameterizations become effective in the model for cells dominated by desert and semi desert land cover. At present, we do not account for sub-grid fractional desert cover, that is a grid point is considered to be either totally covered by desert or with no desert cover.

\subsubsection{Soil aggregate distribution}

In order to characterize the the erodible fraction of different types of soils, soil aggregate distributions are provided to the model. Basically, these distributions rely upon the USDA textural classification, for which different types of soil are classified according to an index referring to the classic clay/sand/silt triangle of texture composition (Hillel, 1982, Table 1). Then a three-mode lognormal soil aggregate diameter distribution, $n(D p)$, is associated to each texture class following Zobler (1986): Table 1 reports the mass mean diameter (MMD, $\mu \mathrm{m})$, standard deviation $(\sigma)$, and soil texture composition used to characterize each textural class. The geographical distribution of this soil information is based on the geographical distribution of soil texture categories widely used in global and meso-scale modeling which are accessible to the public (e.g. at ftp://ftp.ucar.edu/mesouser/MM5V3/ TERRAIN_DATA). Practically the global texture index distributed at $10 \mathrm{~min}$ resolution is aggregated over the simulation domain at the model resolution (typically 20 to $100 \mathrm{~km}$ ) according to the dominant texture type of a given grid cell. 
Table 1. The 12 basic USDA soil texture indices and corresponding soil aggregate size distribution parameters. Soil aggregate sizes are distributed according to a 3 mode lognormal distribution (i referring to the mode):

$$
\frac{d n\left(D_{p)}\right.}{d\left(\log D_{p}\right)}=\sum_{i=1}^{3} \frac{n_{i}}{\log \sigma_{i} \sqrt{2 \pi}} \exp \left[\frac{-\left(\log \left(D_{p} / \mathrm{MMD}_{i}\right)\right)^{2}}{2\left(\log \sigma_{i}\right)^{2}}\right]
$$

where $n\left(D_{p}\right)$ is the cumulative aggregate number distribution in $\mathrm{cm}^{-3}$, MMD is the geometric mean diameter and $\sigma$ the standard deviation in $\mu \mathrm{m}, n_{i}$ is the relative weight of each mode, and $\log \sigma_{i}$ is a measure of aggregate polydispersity.

\begin{tabular}{lcccccccccc}
\hline & \multicolumn{3}{c}{ Mode 1 } & \multicolumn{4}{c}{ Mode 2 } & \multicolumn{3}{c}{ Mode 3 } \\
\hline & $n$ & MMD & $\sigma$ & $n$ & MMD & $\sigma$ & $n$ & MMD & $\sigma$ \\
\hline Sand & 0.90 & 1000 & 1.6 & 0.10 & 100 & 1.7 & 0.00 & 10 & 1.8 \\
Loamy Sand & 0.60 & 690 & 1.6 & 0.30 & 100 & 1.7 & 0.10 & 10 & 1.8 \\
Sandy Loam & 0.60 & 520 & 1.6 & 0.30 & 100 & 1.7 & 0.10 & 5 & 1.8 \\
Silt Loam & 0.50 & 520 & 1.6 & 0.35 & 100 & 1.7 & 0.15 & 5 & 1.8 \\
Silt & 0.45 & 520 & 1.6 & 0.40 & 75 & 1.7 & 0.15 & 2.5 & 1.8 \\
Loam & 0.35 & 520 & 1.6 & 0.50 & 75 & 1.7 & 0.15 & 2.5 & 1.8 \\
Sandy Clay Loam & 0.30 & 210 & 1.7 & 0.50 & 75 & 1.7 & 0.20 & 2.5 & 1.8 \\
Silty Clay Loam & 0.30 & 210 & 1.7 & 0.50 & 50 & 1.7 & 0.20 & 2.5 & 1.8 \\
Clay Loam & 0.20 & 125 & 1.7 & 0.50 & 50 & 1.7 & 0.30 & 1 & 1.8 \\
Sandy Clay & 0.65 & 100 & 1.8 & 0.00 & 10 & 1.8 & 0.35 & 1 & 1.8 \\
Silty Clay & 0.60 & 100 & 1.8 & 0.00 & 10 & 1.8 & 0.40 & 0.5 & 1.8 \\
Clay & 0.50 & 100 & 1.8 & 0.00 & 10 & 1.8 & 0.50 & 0.5 & 1.8 \\
\hline
\end{tabular}

2.2.2 Minimum threshold friction velocity and horizontal saltating mass flux

Soil aggregates can be mobilized if the wind shear at the surface, represented by the wind friction velocity, is sufficiently strong. Marticorena and Bergametti (1995, 1997a, b) showed that the mobilization of a given aggregate size $D_{p}$ becomes effective above the minimum threshold friction velocity $u_{t}^{*}\left(D_{p}\right)$. Assuming that the aeolian shear stress is almost completely transferred to the erodible soil fraction, $u_{t}^{*}\left(D_{p}\right)$ is calculated from the equation:

$u_{t}^{*}\left(D_{p}\right)=u_{t s}^{*}\left(D_{p}\right) \cdot f_{\text {eff }} \cdot f_{w}$

where $u_{t s}^{*}\left(D_{p}\right)$ represents an ideal minimum threshold friction velocity and is determined according to the empirical parameterization of Marticorena and Bergametti (1995):

$u_{t s}^{*}\left(D_{p}\right)=$

$\left\{\begin{array}{l}0.129 \cdot K \cdot[1-0.0858 \cdot \exp \{-0.0617 \cdot(R e-10)\}] R_{e}>10 \\ \frac{0.129 \cdot K}{\left(1.928 \cdot R e^{0.092}-1\right)^{0.5}} 0.03<R_{e} \leq 10\end{array}\right.$

where $R_{e}=a D_{p}^{x}+b$ and $K=\sqrt{\frac{2 \cdot g \cdot \rho_{p} \cdot D_{p}}{\rho_{a}} \cdot\left[1+\frac{0.006}{\rho_{p} \cdot g \cdot\left(2 \cdot D_{p}\right)^{2.5}}\right]}$.

In which $D_{p}$ is the soil radius particle, $\rho_{p}$ is the aggregate density taken to $2.65 \mathrm{~g} / \mathrm{cm}^{3}, \rho_{a}$ is the surface air density calculated by the model, $g$ is the gravitational acceleration. The Reynolds number $R e$ is parameterized according to Marticorena et al. (1997a, b), and b and $\mathrm{x}$ are dimensionless parameters.
The term $f_{\text {eff }}$ in Eq. (1) is a correction factor accounting for the effect of surface roughness. According to Marticorena and Bergametti (1995), $f_{\text {eff }}$ is determined from the partition of wind energy between the erodible surface and the non erodible elements, and is expressed as:

$f_{\text {eff }}=1-\left[\frac{\ln \left(\frac{z_{m}}{z_{0 s}}\right)}{\ln \left(0.35\left(\frac{10}{z_{0 s}}\right)^{0.8}\right)}\right]$

where $Z_{0 s}$ is a roughness length characteristic of a smooth surface (assumed to be $10^{-3} \mathrm{~cm}$ ) and $Z_{m}$ is the grid cell effective roughness length, determined from the land cover specification and the BATS surface scheme.

Finally, $f_{w}$ in Eq. (1) is a factor that accounts for the effect of soil moisture content on the threshold friction velocity. It is parameterized according to Fécan et al. (1999) as:

$f_{w}=\left\{\begin{array}{l}{\left[\begin{array}{l}1+A \cdot\left(w-w^{\prime}\right)^{B} \\ 1 \text { for } w<w^{\prime}\end{array}\right]^{0.5} \text { for } w>w^{\prime}} \\ \text { for }\end{array}\right.$

where $A, B$ and $w^{\prime}$ are based on measurements of the threshold friction velocity for various soil moistures and different soil textures: $A=1.21$, and $B=0.68$ (Fécan et al., 1999), and $w^{\prime}=0.0015 \cdot(\% \text { clay })^{2}+0.17 \cdot(\%$ clay $)$, and $w$ is the prognostic surface volumetric soil moisture calculated by the BATS surface scheme. 
Table 2. Dust emission lognormal size distribution parameters and binding energy $\left(\mathrm{e}_{i}\right)$ attached to each mode (After Alfaro et al. 1998).

\begin{tabular}{lccc}
\hline & Mode 1 & Mode 2 & Mode 3 \\
\hline$D_{i}(\mu \mathrm{m})$ & 1.5 & 6.7 & 14.2 \\
$\sigma_{i}$ & 1.7 & 1.6 & 1.5 \\
$e_{i}\left(\mathrm{~g} \mathrm{~cm}^{-2} \mathrm{~s}^{-1}\right)$ & 3.61 & 3.52 & 3.46 \\
\hline
\end{tabular}

\subsubsection{The horizontal saltating aggregate flux}

The size-dependent expression of the threshold friction velocity is used to calculate the vertically integrated horizontal flux of saltating aggregates. This parameterization accounts for the selective mobilization of the soil aggregates according to their size. The horizontal flux associated to a given saltating aggregate of size $D p$ is given by:

$d H_{F}\left(D_{p}\right)=E \cdot \frac{\rho_{a}}{g} \cdot u^{* 3} \cdot\left(1+R\left(D_{p}\right)\right) \cdot\left(1-R^{2}\left(D_{p}\right)\right) \cdot d S_{\text {rel }}\left(D_{p}\right)$

where $E$ is the ratio of erodible to total surface, $d S_{\text {rel }}\left(D_{p}\right)$ is the relative surface of soil aggregate of diameter $D_{p}$ to the total aggregate surface, determined from the above defined soil aggregate distribution. Finally $R\left(D_{p}\right)$ is the ratio of the threshold friction velocity defined in Eq. (1) to the friction velocity $u *$, calculated within each grid cell from the model prognostic surface wind and the surface roughness height. The total horizontal particle flux is then obtained by the integration of Eq. (5) over $D_{p}$.

\subsubsection{The vertical mass flux of dust transportable particles}

In the sandblasting process, the fine dust transportable particles are released either from saltating soil aggregate disintegration or from surface bombardment by aggregates. Size distributions of such emitted transportable dust particles have been studied by Alfaro et al. (1998). In the model, the emitted dust distribution is fixed according to a three mode lognormal "emission distribution". The corresponding parameters (Table 2) have been taken from Alfaro and Gomes (2001) and are based on specific studies of Saharan aerosols. The dust emission flux corresponding to each emission mode is then calculated as follows.

For a given saltating soil aggregate of diameter $D_{p}$, the dust production depends on the individual kinetic energy of this aggregate. The corresponding kinetic energy flux $d F_{\text {kin }}\left(D_{p}\right)$ is proportional to the horizontal saltation flux (Gillette and Stockton, 1986, 1989; Alfaro et al., 1997; Alfaro and Gomes, 2001) as follows:

$d F_{\text {kin }}\left(D_{p}\right)=\beta \cdot d H_{F}\left(D_{p}\right)$

with $\beta=16300 \mathrm{~cm} \mathrm{~s}^{-2}$ and $d H_{F t}\left(D_{p}\right)$ is given in Eq. (5).
Table 3. Transport bin sizes considered in the model standard version. $f_{c}$ is the fraction of aerosol assumed to be incorporated in cloud droplets, $\alpha_{\text {ext }}$ are the bin specific extinction coefficients obtained from Mie calculations and characteristic of the $350-640 \mathrm{~nm}$ model spectral band. For this band, a refractive index of 1.55$0.0055 i$ as well as a representative size distribution are considered (see text).

\begin{tabular}{lcccc}
\hline Transport bin sizes $(\mu \mathrm{m})$ & $0.01-1$ & $1-2.5$ & $2.5-5$ & $5-20$ \\
$f_{c}$ & 0.3 & 0.15 & 0.05 & 0.05 \\
$\alpha_{\text {ext }}\left(\mathrm{m}^{2} \mathrm{~g}^{-1}\right)$ & 2.85 & 0.86 & 0.37 & 0.13 \\
\hline
\end{tabular}

According to Alfaro and Gomes (2001) the elementary vertical dust particle number flux produced by the aggregate of size Dp within the emission mode $i$ is given by:

$d N_{i}\left(D_{p}\right)=d F_{k i n}\left(D_{p}\right) \cdot p_{i}\left(D_{p}\right) / e_{i}$

Where $e_{i}$ is a binding energy attached to the emission mode $i$ (cf. Table 2), and $p_{i}\left(D_{p}\right)$ is a fraction of the kinetic energy of the saltating aggregate used to release dust particle in the $i$ th emission mode. $P_{i}\left(D_{p}\right)$ is calculated by comparing the individual aggregate kinetic energy $e_{c}\left(D_{p}\right)$ calculated from Eq. (8) to the $i$ th mode binding energy $e_{i}$ according to Alfaro and Gomes (2001).

$e_{c}\left(D_{p}\right)=\rho_{p} \cdot(\pi / 12) \cdot\left(D_{p}\right)^{3} \cdot\left(20 \cdot u^{*}\right)^{2}$

Finally the mass emission flux corresponding to each emission mode is obtained by :

$F_{\text {dust }, i}\left(D_{p}\right)=\left(\frac{\pi}{6}\right) \cdot \rho_{p} \cdot D_{i}^{3} \cdot N_{i}$

Where $N_{i}$ is obtained by the integration of Eq. (7) over the soil aggregate size range, and $D_{i}$ is the median diameter associated to the $i$ th mode (cf. Table 2).

2.3 Transport, gravitational settling and wet removal of dust particles

The above defined dust emission flux is partitioned in a number of size bins that are effectively transported by the model. In the basic configuration adopted in this work this number has been set to 4 (Table 3 ) to reduce computational costs in view of the model application to climate experiments. Each transport-bin is considered as a distinct tracer and is transported according to the tracer transport equation defined in Solmon et al. (2006). This includes transport by resolvable scale winds, sub-grid scale turbulence and deep convection, along with wet and dry removal processes.

Wet deposition is treated following Giorgi (1989) for resolvable scale precipitation and Giorgi and Chameides (1986) for convective precipitation. The fraction of tracer 
contained in cloud water, which can eventually be precipitated, has been fixed as specified in Table 3. These values represent an intermediate hypothesis between purely hydrophobic or purely hydrophilic assumptions found in the literature (e.g. Zender et al., 2003). The values of $f_{c}$, decrease with the bin size as the small particles are more likely to form cloud condensation nuclei.

A new feature of the model in comparison to that decribed by to Solmon et al. (2006) is the addition of a sizedependant particle gravitational settling term and a dry deposition scheme including turbulent transfer in the surface layer and surface interception as a function of land cover characteristic. The dry deposition velocities are calculated as a function of particle size and density and include the contributions of turbulent transfer, Brownian diffusion, impaction, interception, gravitational settling and particle rebound (Giorgi, 1986; Zhang et al., 2001). At the present stage, there is no large scale forcing for dust aerosol and boundary conditions are defined as open.

\subsection{Dust specific extinction coefficient}

Although the dust is not radiatively active in the experiments described here, the dust optical properties need to be calculated for model validation in terms of Aerosol Optical Depth (AOD). These optical properties are computed for each size bin and each spectral band of the RegCM radiation scheme (18 wavelength bands, Kiehl et al., 2001) using Mie theory. Refractive indices which vary for the different bands have been taken from the OPAC database (Hess et al., 1998). For the band $350-640 \mathrm{~nm}$, centered around $500 \mathrm{~nm}$ and used hereafter in model/satellite comparisons, the refractive index is equal to $1.55-0.0055 i$. The above defined three mode emission distribution has been considered as the sub-bin particle size distribution for Mie calculation: Median diameter and standard deviation are listed in Table 2. However, the relative amplitude of each emission mode depends on local and instantaneous wind conditions, soil type and humidity and as do the optical parameters. To estimate representative optical properties, a Mie scattering code has been used considering a set of 16 typical emission particle distribution representing different arid soil component/wind speed combinations. These combinations, and the log-normal parameters are detailed in Alfaro and Gomes (2001). The different extinction coefficients obtained from each of these combinations range, for example, from $1.87 \mathrm{~m}^{2} \mathrm{~g}^{-1}$ for a friction velocity of $35 \mathrm{~cm} \mathrm{~s}^{-1}$ over alumino-silicated silts to $2.99 \mathrm{~m}^{2} \mathrm{~g}^{-1}$ for a friction velocity of $80 \mathrm{~cm} \mathrm{~s}^{-1}$ over coarse sand. "Climatic" extinction coefficients have been obtained by averaging the results of the 16 different combinations for each of the transport bins and reported in Table 3.

Specific extinction coefficient are combined with bin concentrations fields to determine the AOD. In reality, dust optical parameters may vary depending on source region (mineral composition), particle coating and possibly other param- eters (Formenti et al., 2003; Haywood et al., 2003). In the present standard configuration of the dust scheme, this complexity is not accounted for.

\section{Results}

As mentioned, our validation strategy aims at evaluating the model from the episodic to the long temporal scale. The latter is the most critical from the point of view of climate application, but evaluation of individual dust events is a necessary step in order to assess the realism of emission and transport processes. In this section, we validate the three test cases mentioned in Sect. 2 against available observations, using typical grid horizontal resolution for regional climate applications (40 and $60 \mathrm{~km})$.

\subsection{The Northeast Africa case}

During 13 to 16 March 1998, a particularly intense sand storm (Khamasin storm) occurred over northeastern Africa. The main synoptic features of this event are shown in Fig. 1a-d. On 13 March 1998, an anticyclone was centered over the Atlantic Ocean and extended to western Europe, while a cold front associated with a deep depression was located over Algeria. This synoptic low pressure system deepened and moved rapidly along a northeastward trajectory towards the southern Mediterranean coasts, generating strong pressure gradients and surface winds. On 15 March the depression deepened further and swept over northwestern Egypt to eventually cross the eastern Mediterranean and reach the Middle East coasts and Syria on 16 March.

This dust event was simulated with the coupled RegCMdust module using the North African domain shown in Fig. 2 with a horizontal grid spacing of $40 \mathrm{~km}$, which is typical for RegCM. The simulation started on 11 March, 00:00 UTC and ended on 17 March, 00:00 UTC and the results are presented from 13 March to 17 March during the storm event. There were no significant dust emission during the spin-up period from 11 to 13 March. The initial and lateral meteorological boundary conditions necessary to run the RegCM were obtained from ERA40 re-analyses of observations (http://www.ecmwf.int/research/era/).

Figure 2 presents a comparison between the simulated wind at the bottom model level $(\sim 25 \mathrm{~m})$ and the ERA40 reanalysis interpolated onto the model grid at the same level. The instantaneous source magnitudes for the first dust bin are also reported in Figs. 2b, d, f, h. Overall the wind patterns associated with the synoptic depression and its evolution are captured by the RegCM. The main divergence between the reanalysis and simulated fields are found close to the cyclonic center, where the simulated vortices are slightly less intense than compared to the reanalysis. Strong wind currents are reproduced by the model, which cause intense dust emissions especially over the Lybia/Egypt border. Another 

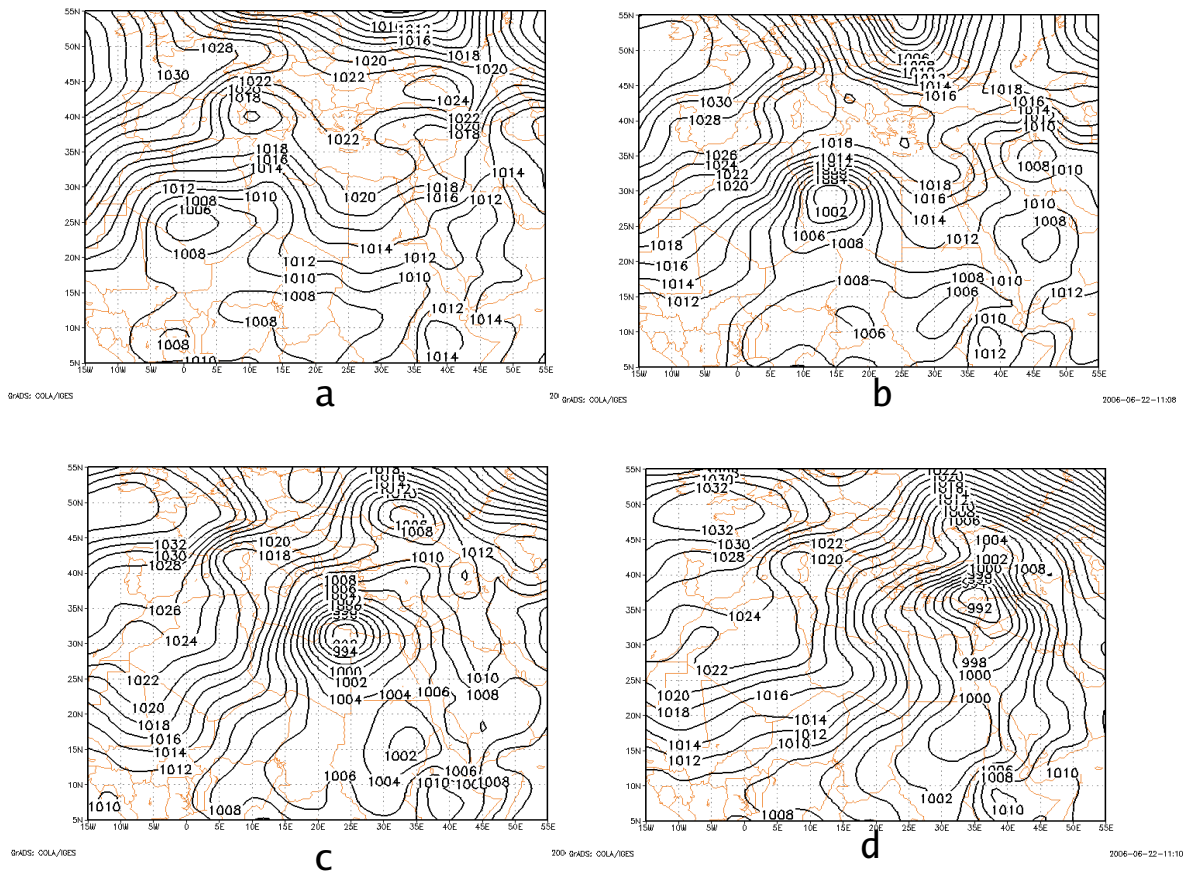

Fig. 1. Synoptic situation during the North African test case. Surface sea-level-pressure charts (mb) from NCEP reanalysis for 12:00 UTC, 13-16 March 1998.

intense dust source is located over the western Lybia/Tunisia border and is activated by a strong northeasterly current on 13 and 14 March.

Dust detection in the near UV is possible using the TOMS aerosol index (AI) (Herman et al., 1997; Torres et al., 1998), which is a measure of the change of spectral contrast in the near UV due to radiative transfer effects of aerosols in a Rayleigh scattering atmosphere. At a first approximation, the TOMS AI can be considered to be proportional to the dust burden and optical depth, so it is a good indication of the dust spatial pattern, and as such it can be used for model validation by comparison with the simulated AOD. This approximation tends to be more valid for aerosols located above $1000 \mathrm{~m}$ altitude (Torres et al., 1998). Therefore we compare to the TOMS AI both the total simulated AOD and the contribution to the AOD deriving from dust above $1000 \mathrm{~m}$.

Figure 3 shows the TOMS AI, the full model AOD and the AOD from dust above $1000 \mathrm{~m}$ for 13-16 March over the model domain. The TOMS AI shows the development of a dust plume over Lybia which essentially follows the trajectory of the low pressure system (Fig. 3). The simulated dust plume moves from west to east across northeastern Africa during 13-15 March. On 16 March the plume starts to move northeastward following the movement of the depression cell. On 15 March, dust-laden air in the Egypt/Libya border moves counter-clockwise following the low-pressure vortex and reaches the northeastern Mediterranean and Syria on 16 March. On 15 March, the observed dust plume shows its maximum intensity over Egypt.
Comparing observed AI and simulated AOD, we notice that 13 March is characterized by relatively low TOMS AI over the analysis area, but moderate plumes over central Lybia can nevertheless be observed in both the simulation and the TOMS observations. On 14 March the TOMS AI shows the development of a plume over the Algeria/Lybia border. Consistent with this pattern, the maximum simulated AOD is obtained close the northern Algeria/Lybia border, immediately south of Tunisia and is linked to local sources in the area (Fig. 3d). The simulated dust source is very efficient there, as shown by the large instantaneous optical depths. Most of the simulated particles are however located in the 0-1000 m near-surface layer as shown by the comparison of Figs. 3e and f. Compared to the AI, we note that this simulated plume is slightly shifted to the west, which may be the result of a misplacement of the source area or differences between simulated and observed local surface winds in the vortex. Also note that part of this local simulated plume generated by northeasterly flow is advected out of the domain and will not be recycled into the domain during the following days.

On 15 March the TOMS AI is at its maximum intensity (Fig. 3g) over northeastern Lybia and northwestern Egypt. The model generally reproduces this maximum well, both for the total AOD and the AOD above $1000 \mathrm{~m}$ (Fig. 3i). Some localized areas of high total AOD are found south of this region of maximum dust in response to the intense sources of large particles, which are quickly removed by sedimentation processes, do not reach the middle troposphere and are not 

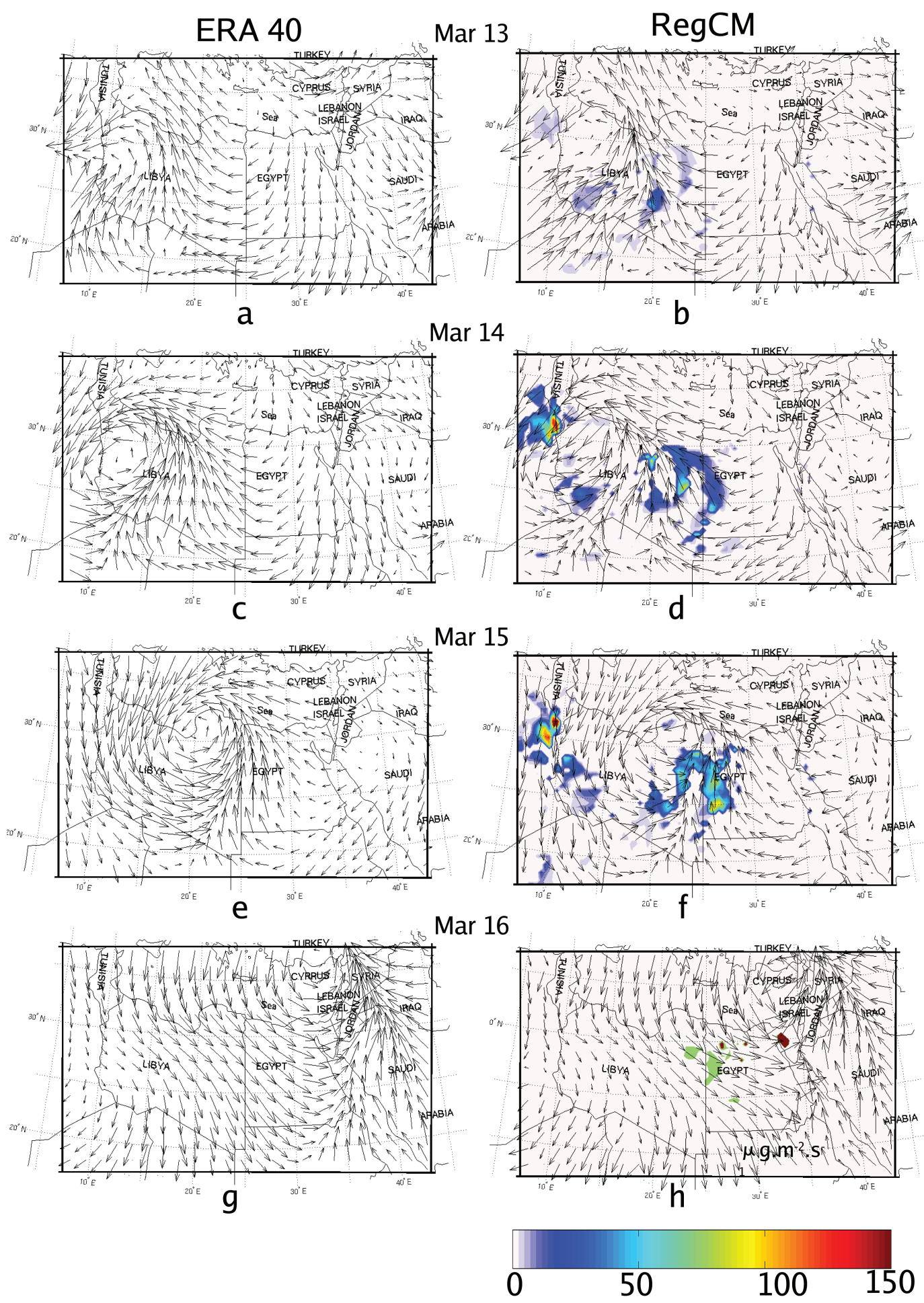

Fig. 2. Comparisons between the RegCM simulated winds at the bottom model level $(\sim 25 \mathrm{~m})$ and $40 \mathrm{~km}$ resolution and the ERA 40 reanalysis. Instantaneous source magnitude for the first dust bin (in $\mu \mathrm{g} \mathrm{m}^{-2} \mathrm{~s}^{-1}$ ) are also displayed for the period 13-16 March 1998.

detected by TOMS. In terms of spatial patterns and location of the maximum dust front, the simulated AOD above $1000 \mathrm{~m}$ appears more consistent with the TOMS AI than the total AOD (Figs. 3h, i). A strong local source and AOD close to the western Lybia border is present in the simulation on 15 March but not in the TOMS AI, despite strong analysed surface winds occur over the area. 
TOMS Al

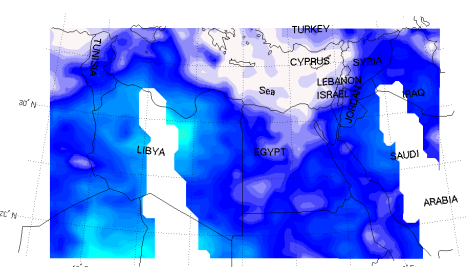

a
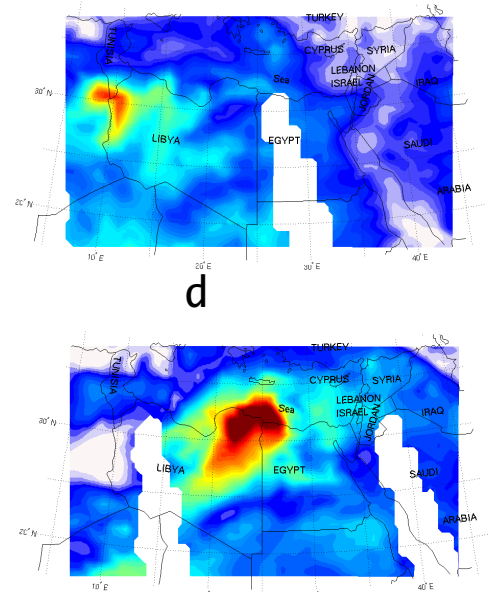

g
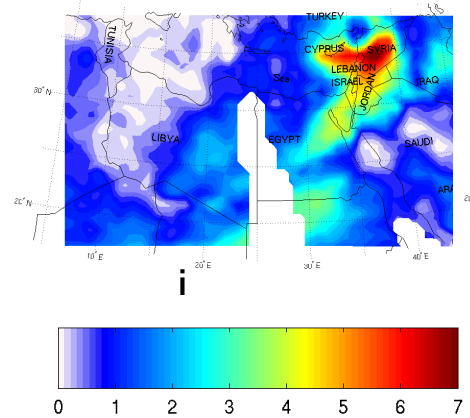

REGCM AOD

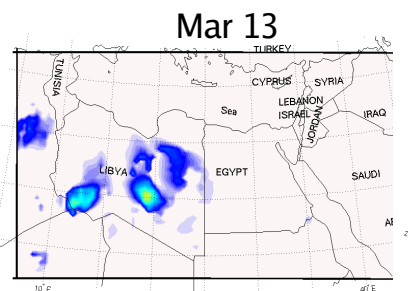

b

Mar 14

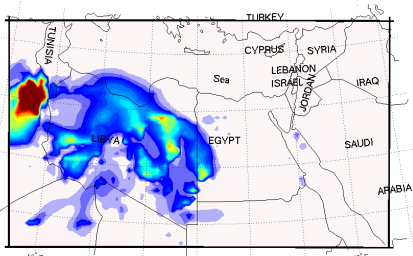

e

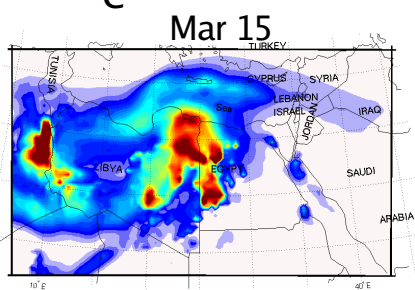

$\mathrm{h}$
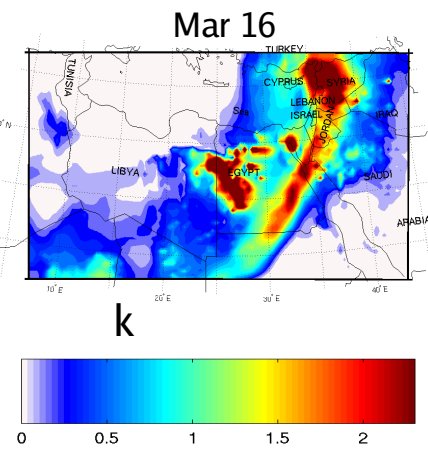

REGCM AOD (>1Km)

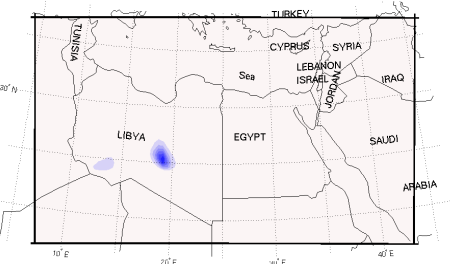

C

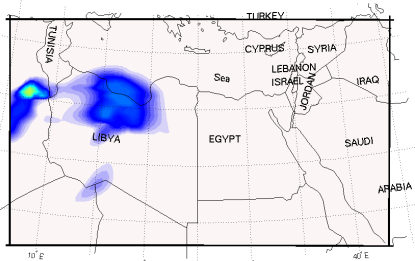

f
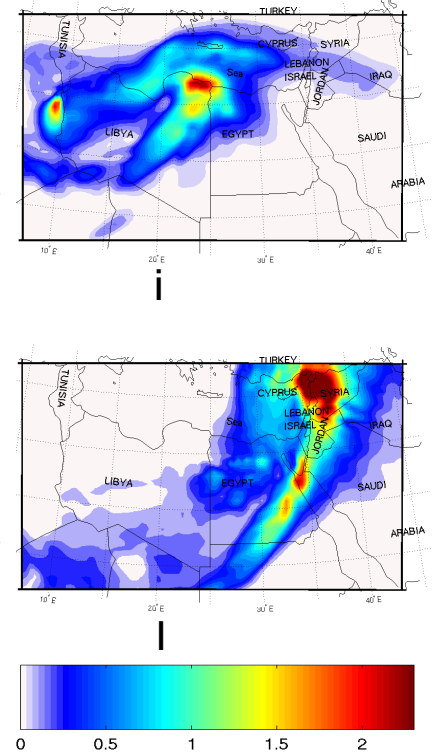

Fig. 3. Comparisons between the simulated total AOD (model band 350-640 nm), simulated AOD at height greater than $1000 \mathrm{~m}$ and TOMS aerosol index during the period 13-16 March 1998.

On 16 March both the TOMS AI and the simulated AOD show a comma-shaped plume extending from Syria to northeastern Egypt. This is produced by the intense cyclonic vortex shown in Figs. 2g, h, and is thus the result of both source and transport processes, thereby showing good model performance in both these features. On 16 March the model also shows large total AOD over central-western Egypt (Fig. 3k). This maximum is not found in both the TOMS AI and the simulated AOD for dust above $1000 \mathrm{~m}$ (Figs. 3j, 1), and therefore it is most likely related to local sources of large particles that are not transported above the near-surface layer and away from the source region.
Conversely, the maximum over Syria is mostly composed of aerosols lying above $1000 \mathrm{~m}$, which implies a strong vertical transport within the core of the cyclonic vortex. This mechanism is illustrated by the vertical cross section of dust concentration and vertical motion on 16 March shown in Fig. 4. We find intense vertical motions that penetrate deeply into the upper troposphere (up to $200 \mathrm{mb}$ ) in the ascending branch of the cylonic vortex located over the eastern Mediterranean. This carries the dust plume all the way into the mid to upper troposphere, with significant dust loadings above $500 \mathrm{mb}$. At these high elevations the horizontal winds are strong, enhancing the horizontal dispersion of the dust plume away from the source region and across long distances is enhanced. 
A further measure of dust dispersion is the so called "ventilation index" (Eagleman, 1996; Hsu, 2003; Rao, 2003), which is defined as the product of the boundary-layer height and a representative boundary-layer horizontal wind speed. The higher these two factors, and thus the ventilation index, the more pronounced the vertical and horizontal dust dispersion. In RegCM the boundary layer height is diagnostically calculated through an iterative technique (Holtslag et al., 1990). As a measure of boundary layer wind we take the wind at the lowest model level, since we are mostly interested in near-surface dust dispersal. Instantaneous values of the ventilation index at 12:00 UTC for 13-16 March 1998, are shown in Fig. 5. This time of day corresponds to the maximum of combined boundary layer height, wind speed and dust burden. Dispersion forecast categories related to atmospheric ventilation (Eagleman, 1996) are reported in Table 4.

Not surprisingly, Fig. 5 shows that the overall spatial and temporal variations in the ventilation index are similar to those found for the dust burden and AOD (see Fig. 3). The maximum ventilation index at $12-\mathrm{h}$ GMT increases from roughly $4000 \mathrm{~m}^{2} \mathrm{~s}^{-1}$ to $9000 \mathrm{~m}^{2} \mathrm{~s}^{-1}$ which corresponds to "good" and "excellent" dispersion categories in Table 4. The corresponding values of boundary layer height vary from about $3.4 \mathrm{~km}$ on 13 March to $3.7 \mathrm{~km}$ on 15 March and $2.5 \mathrm{~km}$ on 16 March (not shown). Therefore, the proportionally larger variations in the ventilation index are attributed to changes in average surface wind speed.

Summarizing the results of this northeast Africa dust outbreak simulation, the model was quite successful in reproducing both the synoptic conditions that lead to the event and the temporal and spatial evolution of the dust plume. Dispersion due to strong surface winds and vertical transport lead to significant dust amounts reaching the upper troposphere and being carried out long distances from the main source regions into the eastern Mediterranean and Middle East areas.

\subsection{The SHADE case}

The second test case we present in this paper is the SHADE experiment which occurred during 20 to 29 September 2000 between the coast of west Africa and the Cabo Verde Islands. During this experiment a detailed study of a dust outbreak, occurring on 25 and 26 September was performed using a combination of in-situ measurements, photometer, lidar and satellite measurements (Tanre et al., 2003; Haywood et al., 2003; Myrhe et al., 2003; Leon et al., 2003; Formenti et al., 2003). For the SHADE period, we performed two 10 day simulations, at $60 \mathrm{~km}$ and $40 \mathrm{~km}$ horizontal grid resolution, starting from 20 September 00:00 UTC and ending on 30 September 00:00 UTC over the domain depicted in Fig. 6. The model was forced by 6 hourly ECMWF ERA40 reanalysis. Here we focus on the special observing period including the 25 and 26 September dust outbreak.

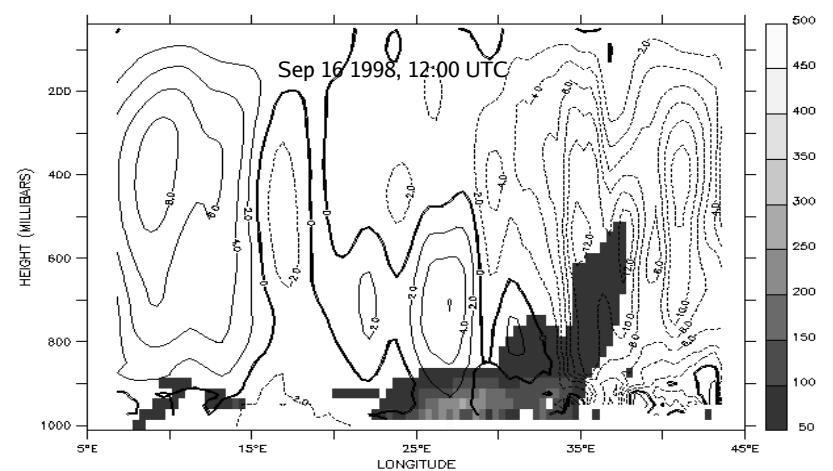

Fig. 4. The longitude-height cross section of dust mixing ratio $\left(\mu \mathrm{g} \mathrm{kg}^{-1}\right)$ and the vertical velocity on 16 March 1998 at 12:00 UTC. Ascending velocities are materialized by dot lines and descending by plain lines.

Table 4. Pollution dispersion forecast categories related to atmospheric ventilation (after Hsu, 2003, and Eagleman, 1996, based on the air pollution dispersal index used by the State of Colorado Dep. of Health, Denver, CO).

\begin{tabular}{ll}
\hline Pollution dispersion & Ventilation $\left(\mathrm{m}^{2} \mathrm{~s}^{-1}\right)$ \\
\hline Bad & $0-2000$ \\
Fair & $2001-4000$ \\
Good & $4001-6000$ \\
Excellent & 6001 or more \\
\hline
\end{tabular}

\subsubsection{Simulated horizontal AOD distribution}

Figure 6 shows the TOMS AI, the total AOD estimated from the Moderate Resolution Imaging Spectroradiometer (MODIS, Tanré et al., 1999) satellite at $550 \mathrm{~nm}$ and the total simulated AOD at 60 and $40 \mathrm{~km}$ over the domain. The satellite acquisition is around 13:00 UTC for MODIS and the model data are shown for 15:00 UTC. To aid the discussion, simulated winds at $40 \mathrm{~km}$ and winds from the ECMWF ERA40 reanalysis at 12:00 UT and $850 \mathrm{hp}$ are also presented in Fig. 7. Figure 8 displays the evolution of daily averaged Aerosol Robotic Network (AERONET, Holben et al., 1998) AOD measurements and simulated AOD at M'Bour (Dakar) and Sal Island for the period of 23-27 September.

On 25 September the TOMS AI (Fig. 6a) shows the development of a dust plume with maximum AI located over west Mauritania. This plume extends over the Senegal coast in response to a strong north-eastern wind current (Fig. 7a). As analyzed during SHADE using back trajectories (Tanré et al., 2003) the main source region for the dust event is West Mauritania but some remote sources are also located in the southwestern Sahara, Mali and south Algeria. Consistently, the MODIS AOD shows a large maximum over the coastal regions of Mauritania and Senegal (up to 1.5 and more in magnitude). 
TIME ; 13-WAR-1998 12:DD [AMTA SET, SPF9803.CCF

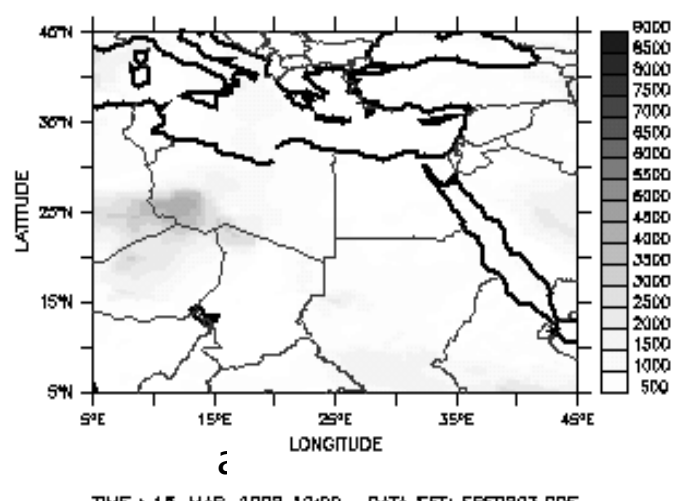

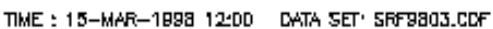

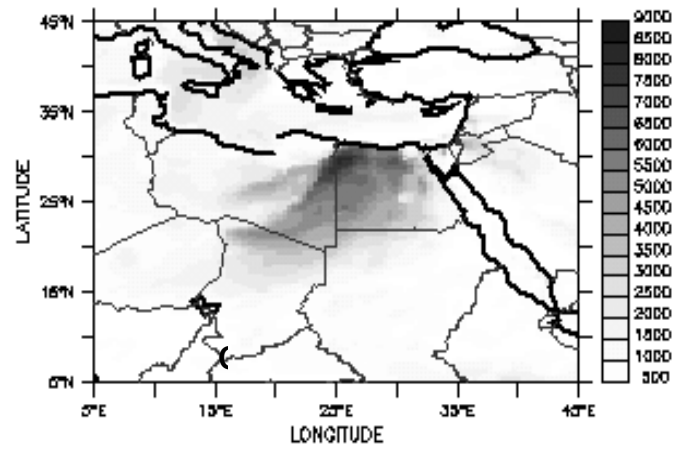

TIME ; 14-WAR-1998 12,00 DA.TA SET, \$RF9203,CDF

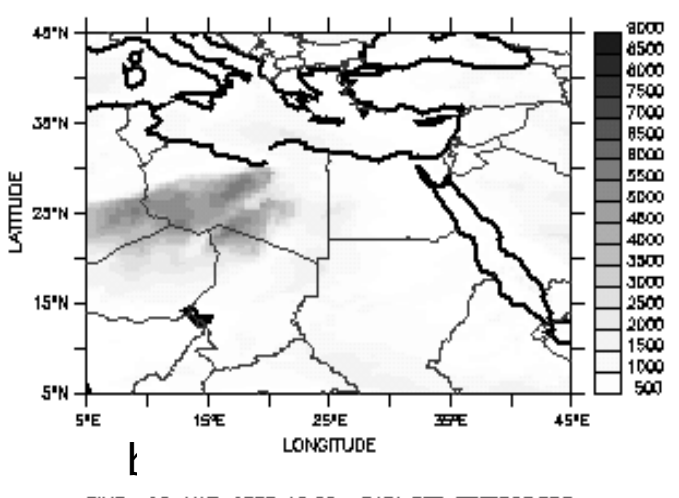

TIWE : 16-WR-1998 12.00 DATA SET BRPBO3 COF

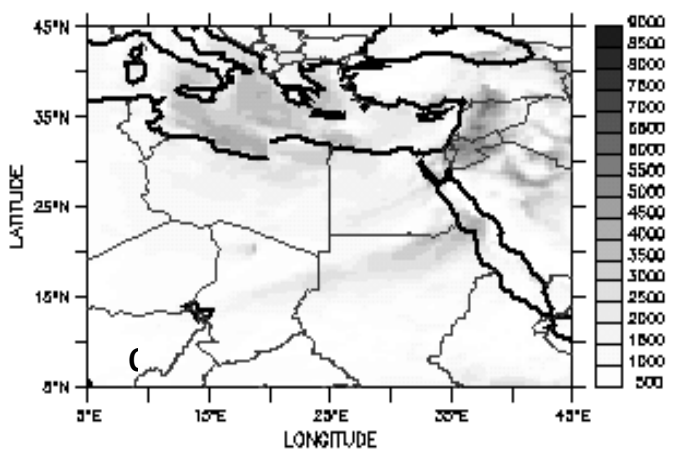

Fig. 5. Ventilation index $\left(\mathrm{m}^{2} \mathrm{~s}^{-1}\right)$ during the dust storm event 13-16 March 1998.

The simulated AOD (Figs. 6e, g) at both $40 \mathrm{~km}$ and $60 \mathrm{~km}$ resolution is maximum over west Mauritania and is generally consistent with the TOMS AI. We note that remote sources over south Algeria and Mali are also well captured. However, the southwest Saharan maximum visible in the TOMS data (Nouadhibou inland region) is not accurately reproduced, being less intense and more localized in the model than in the TOMS data. This underestimation could be due to a less intense simulated north-eastern circulation over the Western Sahara region as illustrated in Figs. 7a and c. Another possible reason for this underestimation is the soil texture representation over this region, which determines the threshold friction velocity. This point will be further discussed below.

The comparison with the MODIS AOD shows that the simulated AOD magnitudes are relatively well represented over the west Mauritania/Nouakchott coastal area. The comparison of observed and analyzed wind patterns upwind of Nouakchott shows that the model reproduces quite well the intensity and direction of the winds there. The simulated AODs over the sea in the Nouakchott outflow region reach a magnitude of 1.5 and are comparable to the MODIS AOD. This indicates that the model is able to realistically represent the Mauritanian dust sources activated by the flow both at 60 and $40 \mathrm{~km}$ resolution.
However, the southward extension of the plume over the northwestern Senegal coast is not accurately reproduced by the model at $40 \mathrm{~km}$ resolution. A comparison between analysed and simulated wind fields shows that the simulated wind field below $15 \mathrm{~N}$ (Figs. 7b, d) differs from the analysis. More specifically, the cyclonic vortex adjacent to the Senegal coasts on 25 September and visible in the ERA40 reanalysis is slightly shifted to the north in the simulation. Consequently, the dust burden resulting from the Mauritanian plume advection and the local dust production in northern Senegal is underestimated on 25 September. This result is particularly visible when comparing the simulated AOD with the local M'Bour AERONET measurements evolution (Fig. 8b).

26 September is characterized by the advection of the dust plume towards the Cabo Verde Islands, as illustrated by the TOMS and MODIS products, as well as the AERONET AOD evolution measured at the Sal station (Fig. 8a). The advection of the dust front to the Cabo Verde islands is captured by the model both at 60 and $40 \mathrm{~km}$ resolution, as illustrated also by the augmentation of the simulated AOD in Sal from 23 to 26 September (Fig. 8). The comparison with the MODIS data over the Cabo Verde region shows also that the maximum AOD at $40 \mathrm{~km}$ resolution is consistent with observations, but underestimated in the $60 \mathrm{~km}$ simulation. The 

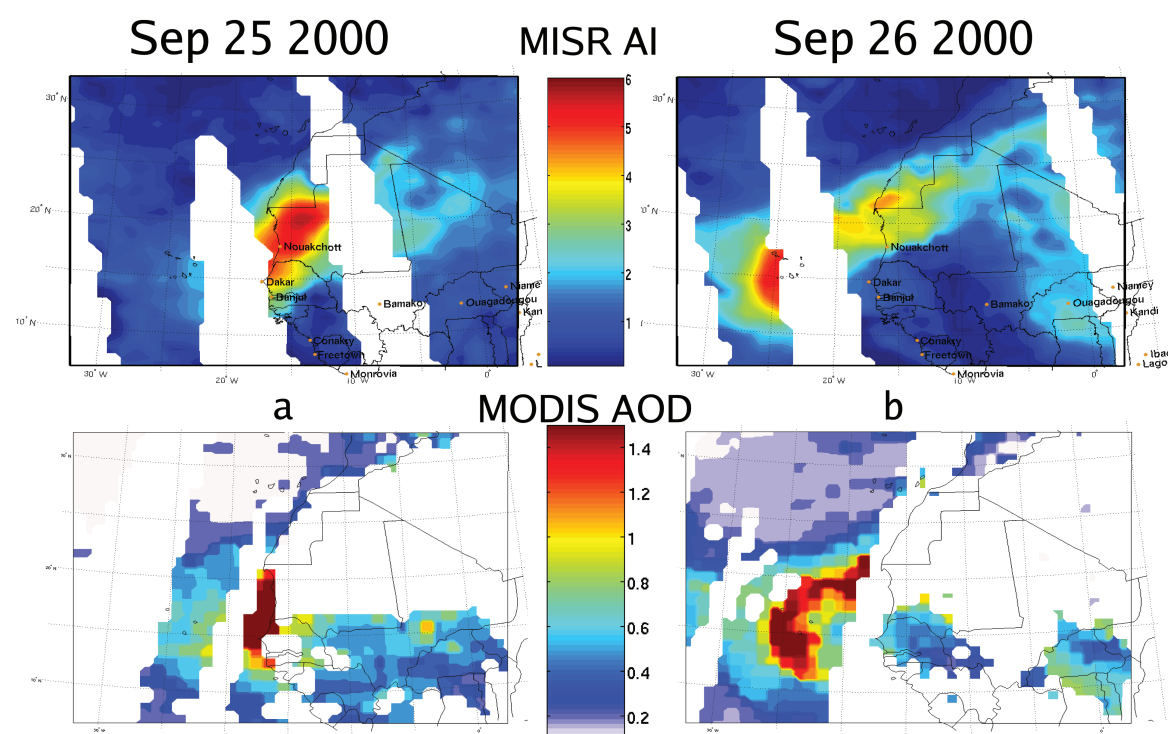

MODIS AOD

b
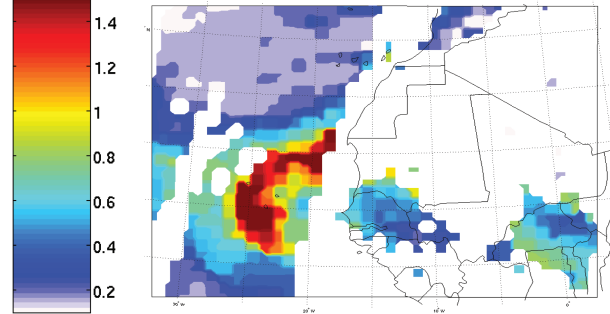

d

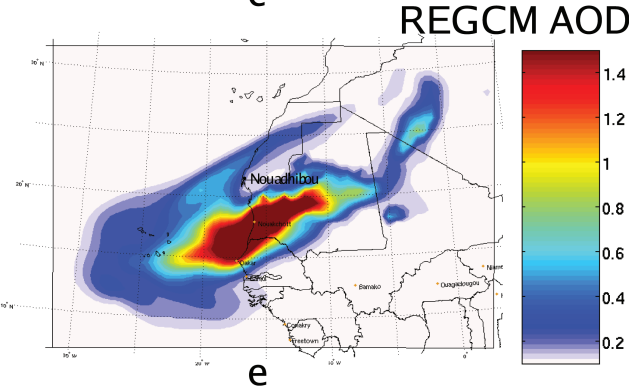

$60 \mathrm{Km}$

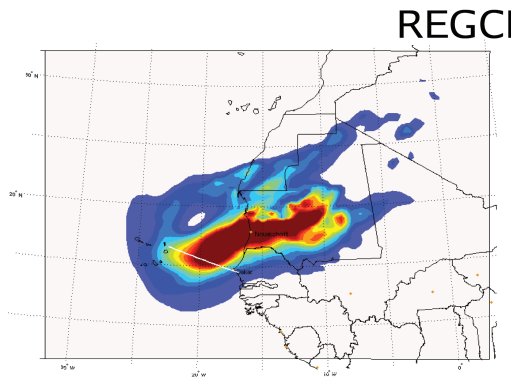

g

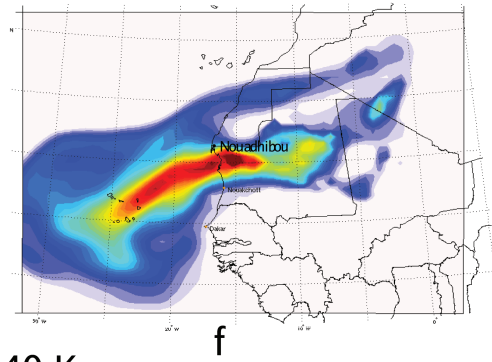

$0 \mathrm{Km}$

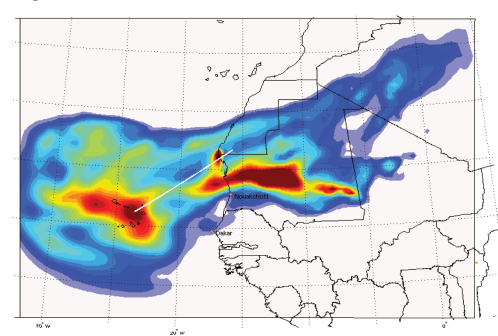

h

Fig. 6. TOMS aerosol index, MODIS Aerosol optical depth at $550 \mathrm{~nm}$ and RegCM simulated Aerosol optical depth (model band 350$640 \mathrm{~nm}$ ) on 25 and 26 September 2000 successively at $60 \mathrm{~km}$ resolution (e, f) and $40 \mathrm{~km}$ resolution (g, h). Model vertical cross sections presented in Fig. 9 and corresponding to flight track during the SHADE experiment are materialized on picture (e) and (f).

westward extension of the plume up to $30 \mathrm{~W}$ is more pronounced in the $40 \mathrm{~km}$ simulation, reflecting a dust production and transport more intense than in the $60 \mathrm{~km}$ resolution, and agreeing reasonably well with the MODIS observation. To the contrary, the $60 \mathrm{~km}$ shows a more consistent structure in the region between the Mauritania coast and $20 \mathrm{~W}$.

(i) For both resolutions, significant differences compared to observations are found: The Mauritanian outflow immediately north of Nouakchott is quite well captured, but the western Sahara southern sources are still under- estimated, except over the Nouadibou source area (cf. Figs. $6 \mathrm{~b}$ and $\mathrm{h}$ ) in the $40 \mathrm{~km}$ simulation. As already mentioned, on 25 September the wind flow over western Sahara is somewhat underestimated (Figs. 7b, d) which possibly leads to an underestimation of western Sahara sources. This underestimation may also be due to the characterization of soil properties: The soil texture aggregation at the model resolution, which is based on the predominant soil class in the grid cell, could potentially lead to the exclusion of some small-scale dust generating areas in the region. By nature this issue is resolution 


\section{ERA40}
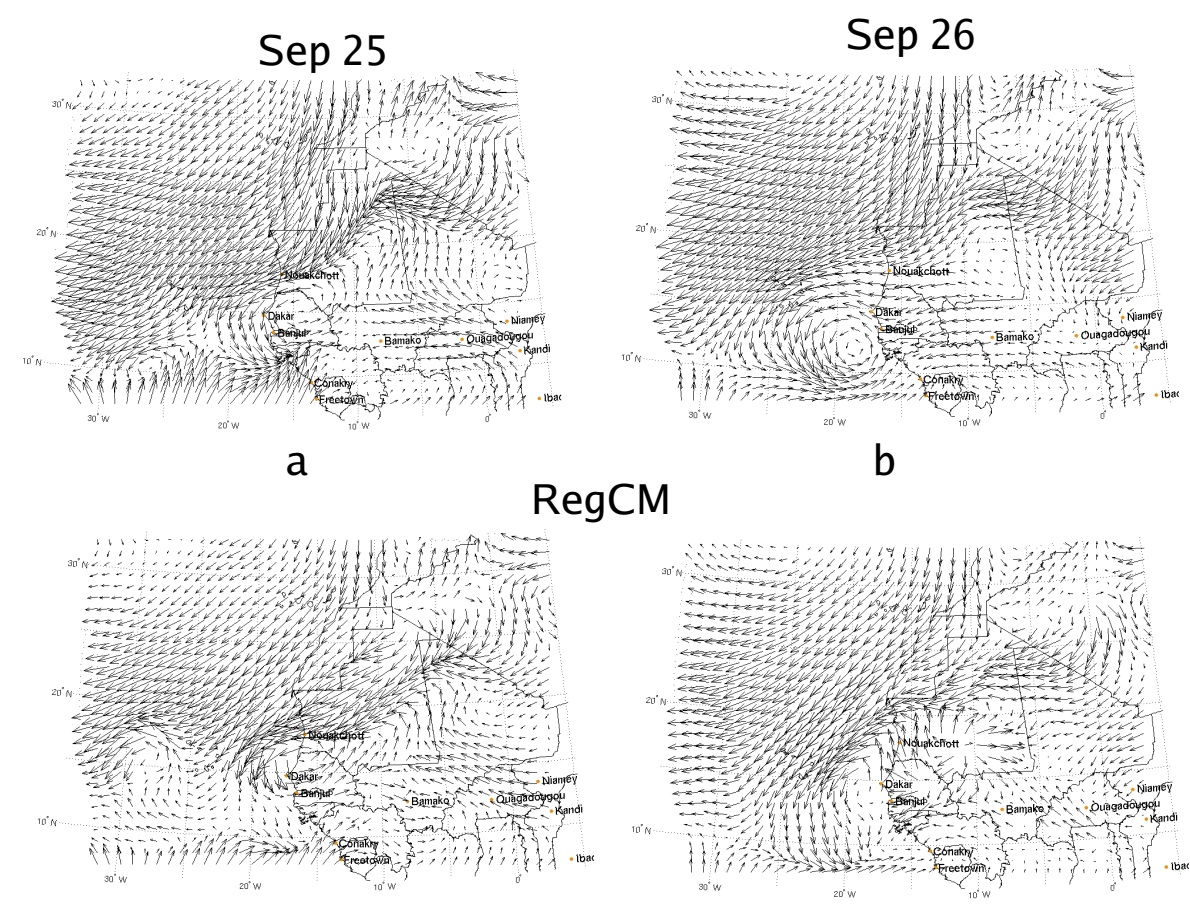

RegCM

C

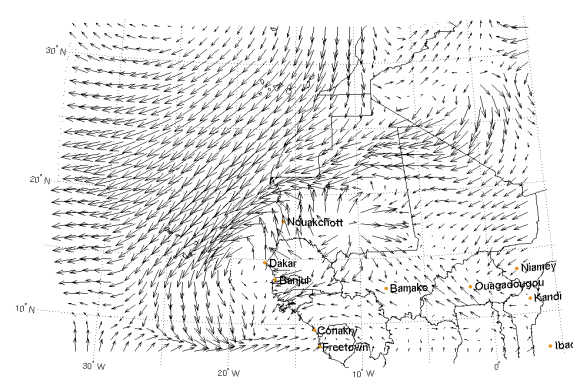

d

Fig. 7. ERA $40 \mathrm{vs.} \mathrm{RegCM} \mathrm{wind} \mathrm{fields} \mathrm{for} \mathrm{the} 40 \mathrm{~km}$ resolution simulation (12:00 UTC) at 850 hpa for 25 and 26 September 2000.

Daily AOD ( $500 \mathrm{~nm})$

AERONET (light gray) /REGCM 23-27 sept 2000

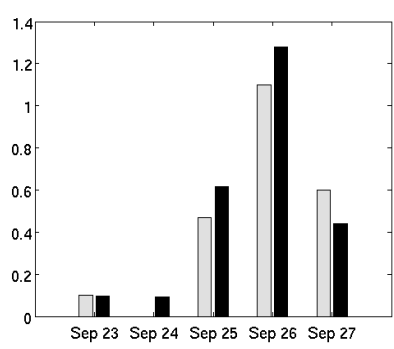

a

Sal, Cabo Verde

16 43' 58" N, 22 56' 06" W

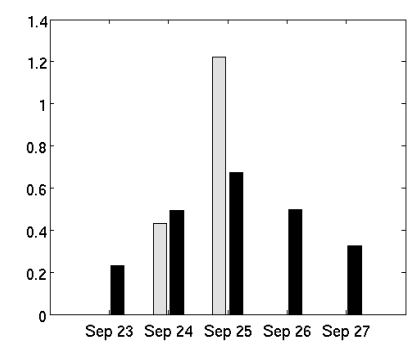

$b$

M'Bour / Dakar, Senegal

$1423^{\prime} 38^{\prime \prime} \mathrm{N}, 1657^{\prime} 32^{\prime \prime} \mathrm{W}$
Fig. 8. AERONET vs. RegCM daily AOD (model band 350$640 \mathrm{~nm}$ ) at Sal and M'Bour location for the period 23 to 27 September. For Sal AERONET values are missing on 24 September. For M'Bour, AERONET value are missing on 23, 26 and 27 September.

dependant as illustrated by the difference of simulated AOD over the Nouadibou spot (Figs. 6f, g). Uncertainties in the BATS specification of roughness length over desert regions might also play a role in this regard. The underestimation of the western Sahara sources affects directly the magnitude of the simulated AOD over the sea when compared to the MODIS AOD. (ii) A comparison of the $40 \mathrm{~km}$ simulated and analyzed wind patterns for 26 September shows that the intense cyclonic circulation associated with a low in the Guinea coastal region is not simulated accurately (Figs. 7b, d). The low pressure system is not well organized in the simulation. This has two consequences on the dust plume. First, between the Nouakchott and Dakar source area, the simulated wind field is not adequately represented in direction and intensity, thus the dust source contributing to the west Mauritania outflow is underestimated. Secondly, the simulated plume tends to lose the observed northerly direction (Figs. 6d and f) associated with the cyclonic circulation below $15 \mathrm{~N}$. As illustrated on Figs. 6f, h, the structure of the dust front is slightly better represented at $40 \mathrm{~km}$ resolution compared to $60 \mathrm{~km}$ resolution. We tested the sensitivity of the simulation of this cyclonic vortex to different convection schemes available in the model and and significant impact on the plume development were found. This is an indication that the model is characterized by a large internal variability in tropical regions (as also found by Giorgi and Bi, 2000), which affects the simulation of individual events, but should be less critical for long term climate simulations. 


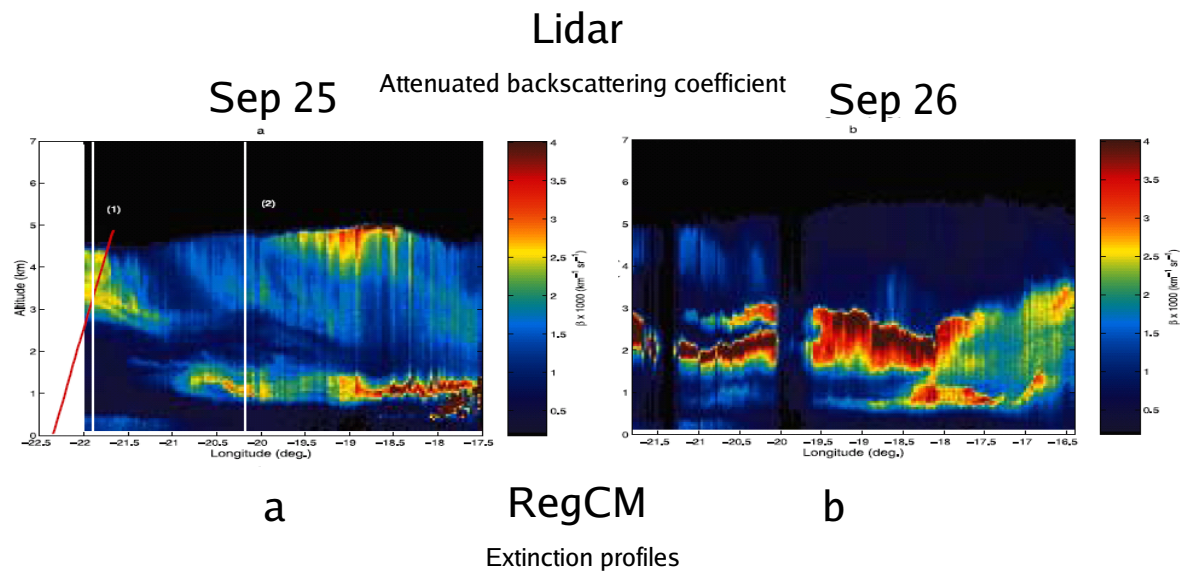

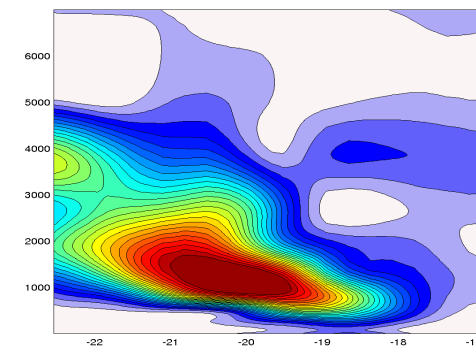

C

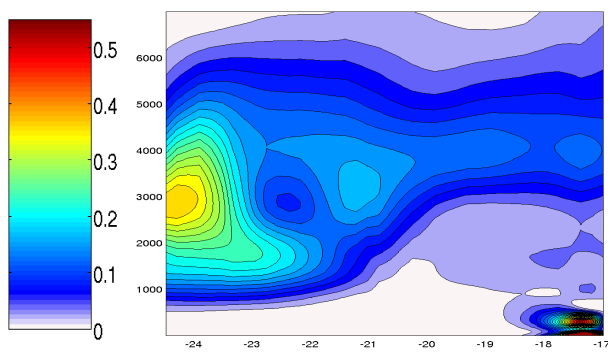

d

Fig. 9. Lidar attenuated backscattering coefficients measured during SHADE experiment on (a) 25 September and (b) 26 September (taken from Léon et al., 2003). Simulated RegCM dust extinction profiles on (c) 25 September and (d) 26 September. The vertical cross sections were performed along the tracks materialized on Fig. 6 .

\subsubsection{Vertical structure of the dust plume in the outflow re- gion}

The SHADE experiment provided data for the characterization of the vertical structure of the dust outbreak by use of lidar measurements along plane trajectories as well as local drop sound measurements (Léon et al., 2003; Tanré et al., 2003). Here, we compare simulated vertical cross sections of extinction to lidar back scattering coefficients taken from Léon et al. (2003). The lidar measurement is linked to the aerosol extinction as described by Léon et al. (2003). As a first order approximation, we assume that both the lidar and modeled extinction profiles are proportional to the actual amount of dust in a given atmospheric layer. Rather than assessing the absolute magnitude, we instead focus on the relative magnitude and position of the simulated vs. observed dust layers. The simulated values at $40 \mathrm{~km}$ resolution have been interpolated from the original sigma level grid to a regular height grid for comparison. Note that the model was run at its standard configuration (targeted for climate applications) which includes 18 vertical sigma levels with a midtropospheric resolution of about $90 \mathrm{hPa}$. This is admittedly a relatively coarse vertical resolution.
Figures $9 \mathrm{a}, \mathrm{b}$ and $9 \mathrm{c}, \mathrm{d}$ compare the simulated and lidar cross sections along the track of the M20 airplane between Dakar and the Cabo Verde islands (the cross section traces are shown in Figs. $6 \mathrm{~g}$ and $\mathrm{h}$ ). Both the model and the observations reproduce the presence of a dust layer over the marine boundary layer. Léon et al. (2003) and Tanré et al. (2003) point out the existence of a first dust layer located at around $1000-1500 \mathrm{~m}$ (visible in Fig. 9a, b) originating from western Mauritania and northern Senegal. Between 17.5 and $20 \mathrm{~W}$, the model does produce a first continuous layer of dust starting from about $1000 \mathrm{~m}$ around $18 \mathrm{~W}$, then thickening slowly in the westward direction. This simulated layer corresponds well with the observed Mauritanian layer. The very thick dust layer observed at low levels at $17.5 \mathrm{~W}$ (i.e. close to the coast) in Fig. 9a is not reproduced by the model. The reason for this lies in the above discussed dust burden underestimation and misrepresentation of sources in the west Senegal region on 25 September.

When moving westward and northward along the flight track (Figs. 6e and 9a) a distinct dust layer around 3500 $4000 \mathrm{~m}$ appears in the RegCM simulation. Such a layer originating from remote west Saharian and Algerian sources is also observed in the lidar profile (Fig. 9a). From $20.5 \mathrm{~W}$ to $22.5 \mathrm{~W}$, we can see that the two simulated layers tend to 

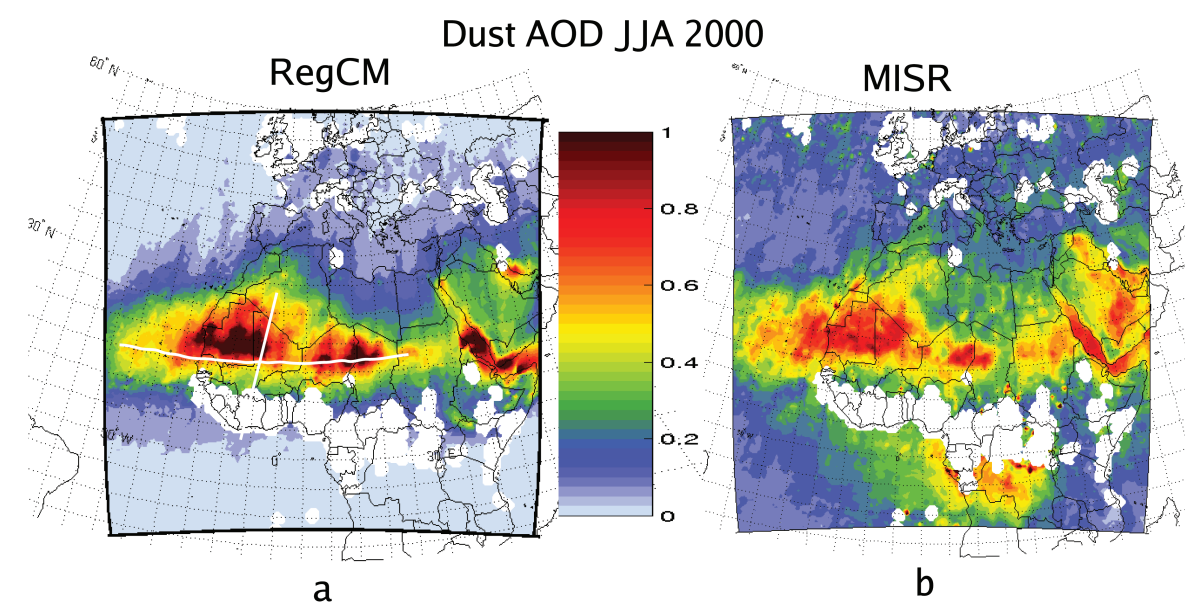

Fig. 10. RegCM (model band 350-640 nm) vs. MISR seasonal average of aerosol optical depth for JJA 2000. Vertical cross section presented in Fig. 12 are materialized on picture (a).

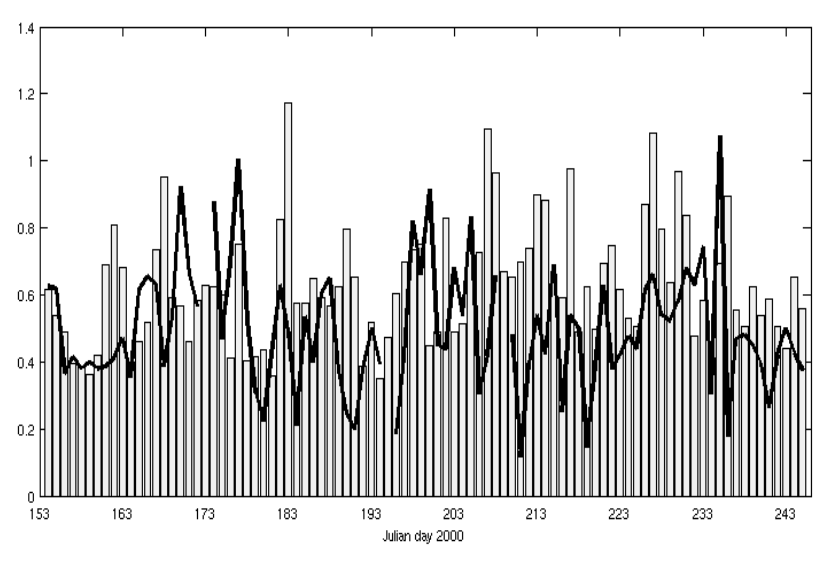

Fig. 11. Seasonal comparison of daily model AOD (model band 350-640 nm, bar) and AERONET AOD (averaged of the $440 \mathrm{~nm}$ and $670 \mathrm{~nm}$ photometer band, line) at Cabo Verde for JJA 2000.

merge progressively, a feature not found in the lidar cross section and likely due to the relatively coarse model vertical resolution. Also on 25 September the lidar cross section shows a dust layer above $3000 \mathrm{~m}$ between 17 and $20 \mathrm{~W}$. The model reproduces the presence of this layer, although its magnitude appears underestimated.

On 26 September the lidar cross section between Nouadibou and Sal Island (Fig. 6d) reveals a deep aerosol layer located between 2000 and $3000 \mathrm{~m}$ west of $17.5 \mathrm{~W}$. Close to the coast, a thin dust layer located around $1000 \mathrm{~m}$ is also still observable. At a higher altitude, a layer from remote Algerian sources is also observed (Tanré et al., 2003). Figure 9d presents the simulated vertical extinction cross section along a similar, but somewhat extended, flight path. Compared to the lidar cross section, the model misses the layer observed between $18 \mathrm{~W}$ and $21 \mathrm{~W}$, mainly because of the discrepancies in the plume dynamical evolution described above: referring to the horizontal AOD, we find that the vertical cross section does not intercept the dust plume as it does in the SHADE experiment. However, the simulated outflow layer maximum above the Cabo Verde Islands (22-24 W) is located between 2500 and $3500 \mathrm{~m}$, which is consistent with the observed outflow height. Again, due to the relatively coarse vertical grid resolution, the model does not capture precisely the observed strong stratification of this layer.

Close to the coast area (around $17 \mathrm{~W}$ in Fig. 9b, d) both the model and the observations show the evidence of thick low level dust layers close to the sources. In the simulation, the Nouadibou dust plume is particularly visible. Around $4000 \mathrm{~m}$ altitude and between 17 and $20 \mathrm{~W}$, some relative maxima linked to remote sources are visible in the model cross section. This result appears consistent with the upper level dust layer observed in the lidar cross section.

In summary, although this test case is negatively affected by errors in the simulation of the cyclonic vortex off the Senegal coasts on 26 September and by the relatively coarse model vertical resolution, the model is able to reproduce a number of the observed features of the dust plume development for the SHADE case, concerning both its horizontal and vertical structure.

\subsection{The "climate mode" simulation}

In order to test the model performance in "climate mode" we carried out a 3 months simulation of JJA 2000 over an extended domain covering the Europe-Africa sector (see Fig. 10) at $60 \mathrm{~km}$ grid spacing. This is the same domain used by Solmon et al. (2006) and boundary conditions for the simulation are again obtained from ERA40 reanalyses. In our analysis of this case, we do not focus on specific dust emis- 


\section{RegCM Dust (JJA 2000) extinction profiles}
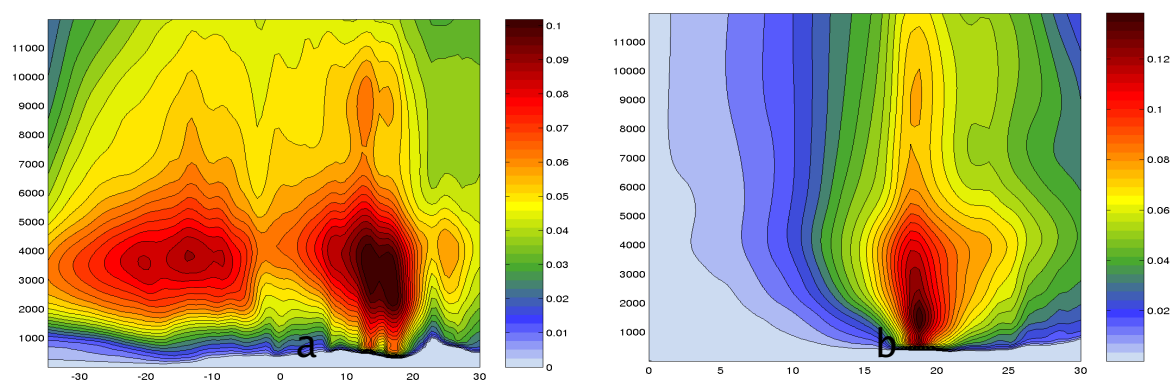

Fig. 12. RegCM simulated seasonal extinction profile along a (a) East-West cross section and (b) North-South cross-section for JJA 2000.

sion events but on the aggregate dust amounts in the simulation period.

Figure 10 presents a comparison of satellite AOD data inferred from the MISR (Martonchick et al., 1998) satellite sensor and the corresponding simulated AOD. Following a method similar to Schulz et al. (1998), a composite seasonal average of model AOD has been created for this comparison by screening model daily output with coincident daily MISR observations over JJA 2000.

In JJA, the emission of carbon aerosols from biomass burning is minimum over the Sahel region (Liousse et al., 1996), so that the aerosol AOD over this region in the MISR data is dominated by the contribution of desert dust. In sub equatorial Africa, most of the AOD detected by MISR is related to biomass burning aerosols, which are not included in the present simulation and won't be discussed further.

In the satellite observations, major dust regions are located across a belt encompassing Mauritania, Mali, central Niger, central-eastern Chad and northern Sudan. We also note the dust plume transported across the eastern Atlantic and the high dust loads along the Red Sea, which are tied to flow convergence and related transport from the surrounding desert. The model generally captures all these features of the observed dust distribution, albeit with some differences compared to the measurements: the simulated dust plume appears more concentrated than observed over the Mauritania-Mali region and the dust load is underestimated over north-eastern Sudan. The dust outflow into the Atlantic is well captured by the model. The southern extent of the dust plume over the Sahel, limited by the mean African Monsoon flux in JJA, is well captured. This feature is encouraging in view of the application of the model to study dust-monsoon interactions at climatic time scales.

Figure 11 present a seasonal local comparison between simulated AOD and AERONET data at Cabo Verde situated in the Saharan outflow. AOD data show a strong temporal variability linked to specific dust events. This variability is also present in model outputs. Overall, the average AOD magnitude and evolution is consistently reproduced by the model (cf. Fig. 11). Some of the specific events are also captured. However as illustrated in the SHADE test case, simulated plume trajectories can deviate from observations, and getting an adequate local representation of each event is still difficult.

Figure 12 shows an east-west and a north-south cross section of average JJA simulated dust amounts (performed without specific screening) across the tracks indicated in Fig. 10, where the main dust regions are located. In both cross sections we see the tendency of the model to produce different dust layers, one close to the surface source and one in the mid-troposphere, between 2000 and $5000 \mathrm{~m}$, caused by vertical convective and large scale transport. A high layer, resulting from deep convective transport and/or remote sources, is also simulated. This layer structure appears consistent with what has been observed, for example in the SHADE case. The east-west transect shows that the dust reaching the midtroposphere is mostly transported in a westward direction by the equatorial easterlies, contributing to the Atlantic outflow. Conversely, the north-south transect suggests a weak meridional transport from the Sahel, with the dust plume being mostly confined between $15 \mathrm{~N}$ and $25 \mathrm{~N}$. The descending motion associated with the Saharan sub-tropical high inhibits large scale meridional transport, and Saharan dust flow into the Mediterranean and European regions is mostly associated with episodic synoptic scale events (as illustrated for example in our northeast Africa case).

Beside the south Sahara source and Saharan outflow regions, the large dust amounts over the Red Sea are captured but slightly overestimated (Fig. 10). In the simulation, we note that the simulated dust slightly affects the AOD over Western Europe and that seasonal AOD in southern Mediterranean and North Africa are a bit underestimated compared to MISR.

Differences between observed and simulated dust loads in source regions may be related to the lack of sub-grid fractional dust sources in the model, where the dust source area 
at a given grid cell depends on the prevalent soil and land cover type and is equal to either 1 or 0 . This may lead to an underestimation in emissions in grid cells with low fractional dust generation areas (that are now neglected by the model) and an overestimation of emissions in grid boxes of large (but less than 1) fractional dust generation areas. As a result of this problem, the dust distribution in the model would show more patchy patterns than in the observations.

\section{Discussion and conclusions}

In this paper we implemented a dust aerosol scheme including emission, transport, gravitational settling, removal and optical property calculations within the regional climate model RegCM. As a first order validation, the model was applied to three test cases, covering temporal scales from episodic (few days), to seasonal ("climate mode"). The first test case focused on a northeast Africa dust storm, the second on the west Africa SHADE dust outbreak, and the third was a simulation of JJA 2000 for the extended Africa/Europe domain. Comparison with observations for the three cases leads to the following points of conclusion and discussion:

- The RegCM-Dust model is able to simulate the occurrence of strong dust outbreaks in different regions and dynamical situations. Many observed features of the horizontal and vertical structure of the dust outbreaks over the eastern Mediterranean basin and the western Sahara, which are key regions in terms of regional aerosol climatic impacts (e.g. Lelieveld et al., 2002), are simulated well.

- The greatest model deficiency occurred in the SHADE case, when the model failed to reproduce the observed development of a cyclonic low on 26 September. This obviously affected the quality of the dust simulation, however the problems were essentially tied to the dynamical part of the model and not the dust module. The simulation of the details of meso-scale systems associated with African easterly waves is difficult in climate models (Jenkins et al., 1997), and may depend on many factors, such as model resolution as illustrated on the SHADE case, but also model physics and notably convection, model boundary forcing, model internal variability etc. In the present experiments we used standard model configuration and resolution for application to climate runs, without any specific regional optimization. The model showed a better performance in simulating the dynamical evolution of the northeastern Africa outburst, which was primarily associated to a synoptic scale event. More generally, the performance in simulating details of specific events may not be a critical issue within the context of climate simulations.

- In the SHADE case, when the dynamics was captured satisfactorily, the AOD magnitudes were consistent with observations. This result indicates that the emission flux scheme produces reasonable dust burdens over the main source regions (west Mauritania, southwest Algeria). A similar conclusion is drawn from the northeast Africa case. Some local misrepresentation of soil and surface characteristics, as well uncertainties in the emission scheme itself, may lead to a misrepresentation of local sources. This issue is likely to be resolutiondependent and we are planning to incorporate and test in the model a sub-grid representation of soil texture and vegetation types, as well as the use of alternative land use classifications.

- In the seasonal simulation the model captured the spatial distribution of the main dust load areas over the Sahel, along with the magnitude of the average AOD. The simulated distribution of dust areas was however more concentrated than in the observations, possibly as a result of the above mentioned lack of sub-grid fractional dust emission parameterization in the model. The average dust profile over the Sahel showed a typical twolayered structure, with one layer close to the surface in source regions and the other placed between 2000 and $5000 \mathrm{~m}$. The aerosol seasonal vertical structure is important to address semi-direct and indirect effects. In this regard, forthcoming observational campaigns (e.g. as AMMA) should provide necessary data sets to better validate this aspect of the model.

Overall, the simulations analysed here give encouraging indications concerning the use of our dust model for climate application. We are planning to conduct long term multiyear integrations including dust and other aerosols (Solmon et al., 2006) radiatively active within the RegCM to study the effects of the aerosol radiative forcing on the climate of Africa and the Mediterranean region.

Acknowledgements. We would like to thank I. Seidou Sanda for his work on RegCM and dust radiative properties. Thanks also to F. Dulac as well as the other anonymous reviewers for their constructive comments. Thanks to N. Elguindi for manuscript proofreading.

Edited by: Y. Balkanski

\section{References}

Alfaro, S. C., Gaudichet, A., Gomes, L., and Maille, M.: Mineral aerosol production by wind erosion: aerosol particle sixes and binding energies, Geophys. Res. Lett., 25, 991-994, 1998.

Alfaro, S. C., Gaudichet, A., Gomes, L., and Maille, M.: Modeling the size distribution of a soil 5 aerosol produced by sandblasting, J. Geophys. Res., 102, 11 239-11 249, 1997.

Alfaro, S. C. and Gomes, L.: Modelling mineral aerosol production by wind erosion: Emission intensities and aerosol size distributions in source areas, J. Geophys. Res., 106, 18 075-18 084 2001. 
Bagnold, R. A.: The physics of Blown sand and Desert Dunes, 265 pp., Methuen, New York, 10, 1941.

Cakmur, R. V., Miller, R. L., and Torres, O.: Incorporating the effect of small scale circulations upon dust emission in an AGCM, J. Geophys. Res., 109, D07201, doi:10.1029/2003JD004067, 2004.

Cakmur, R. V., Miller, R. L., Perlwitz, J., Koch, D., Geogdzhayev, I. V., Ginoux, P., Tegen, I., and 15 Zender, C. S.: Constraining the global dust emission and load by minimizing the difference between the model and observations, available at: http: //pubs.giss.nasa.gov/authors/rmiller.html, J. Geophys. Res., in press, 2006.

Dickinson, R., Henderson-Sellers, A., and Kennedy, P.: Biosphereatmosphere transfer scheme (bats) version 1e as coupled to the NCAR community climate model, Technical report, Na-20 National Center for Atmos. Res., 1993.

Eagleman, J. R.: Air pollution meteorology, Trimedia Publishing Co., Lenexa, KS, 258 pp, 1996.

Fecan, F., Marticorena, B., and Bergametti, G.: Parameterization of the increase of aeolian erosion threshold wind friction velocity due to soil moisture for arid and semi-arid areas, Ann. Geophys., 17, 149-157, 1999, http://www.ann-geophys.net/17/149/1999/.

Formenti, P., Elbert, W., Maenhaut, W., Haywood, J. M., and Andreae, M. O.: Chemical com- composition of mineral dust aerosol during the Saharan Dust Experiment (SHADE) airborne position campaign in the Cape Verde region, September 2000, J. Geophys. Res., 108(D18), 8576, doi:10.1029/2002JD002648, 2003.

Gillette, D. A. and Hanson, K. J.: Spatial and temporal variability of dust production caused by wind erosion in the United States, J. Geophys. Res., 94, 2197-2206, 1989.

Gillette, D. A. and Stockton, P.: Mass momentum and kinetic energy fluxes of saltating particles, in: Aeolian Geomorphology, edited by: Nickling, W. G., Allen and Unwin, Winchester, Mass, 35-56, 1986.

Gillette, D. A. and Stockton, P.: The e_ect of nonerodible particles on wind erosin of erodible surfaces, J. Geophys. Res., 94, 12 885-12 893, 1989.

Giorgi, F. and Mearns, L. O.: Introduction to special section: Regional climate modeling revis-revisited, J. Geophys. Res., 104, 6335-6352, 1999.

Giorgi, F. and Chameides, W. L.: Rainout lifetimes of highly soluble aerosols and gases as inferred from simulations with a general circulation model, J. Geophys. Res., 91, 14 367-14376, 1986.

Giorgi, F. and Bi, X.: A study of internal variability of a regional climate model, J. Geophys. Res., 105, 29 503-29 521, 2000.

Giorgi, F.: A particle dry deposition parameterization scheme for use in tracer transport models, J. Geophys. Res., 91, 9794-9806, 1986.

Giorgi, F., Marinucci, M., and Bates, G.: Development of a second generation regional climate 15 model (RegCM2). Part I: Boundary layer and radiative transfer processes, Mon. Wea. Rev., 121, 2794-2813, 1993a.

Giorgi, F., Marinucci, M., Bates, G., and DeCanio, G.: Development of a second generation regional climate model (RegCM2). Part II: Convective processes and assimilation of lateral boundary conditions, Mon. Wea. Rev., 121, 2814-2832, 1993b.

Giorgi, F.: Two-dimensional simulations of possible mesoscale e_ects of nuclear war fires. I: Model description, J. Geophys. Res., 94, 1127-1144, 1989.

Gong, S. L., Zhang, X. Y., Zhao, T. L., McKendry, I. G., Ja_e, D. A., and Lu, N. M.: Characteriza- Characterization of soil dust aerosol in China and its transport and distribution during 2001 ACE-Asia: 2. tion Model simulation and validation, J. Geophys. Res., 108, 4262, doi:10.1029/2002JD002633, 2003.

Grell, G. A., Dudhia, J., and Stauffer, D. R.: A Description of the Fifth-generation Penn State/NCAR Mesoscale Model (MM5), NCAR Technical Note, NCAR/TN-389+STR, 138 pp, 2004.

Grell, G. A.: Prognostic evaluation of assumptions used by cumulus parameterizations, Mon. Wea. Rev., 121, 764-787, 1993.

Haywood, J., Francis, P., Osborne, S., Glew, M., Loeb, N., Highwood, E., Tanr ' e, D., Myhre, G., Formenti, P., and Hirst, E.: Radiative properties and direct radiative e_ect of Saharan 1774 dust measured by the C-130 aircraft during SHADE: 1. Solar spectrum, J. Geophys. Res., 108(D18), 8577, doi:10.1029/2002JD002687, 2003.

Herman, J. R., Bhartia, P. K., Torres, O., Hsu, C., Seftor, C., and Celarier, E.: Global distribu- distributions of UV-absorbing aerosols from Nimbus 7/TOMS data, J. Geophys. Res., 102, 16911-16922, 1997.

Hillel, D.: Introduction to soil Physics, 364 pp., Academic, San Diego, Calif, 1982.

Holben, B. N., Eck, T. F., Slutsker, I., Tanr' e, D., Buis, J. P., Stezer, A., Vermote, E., Reagan, Y., Kaufman, U. J., Nakajima, T., Lavenu, F., Jankowiak, I., and Smirnov, A.: AERONET-A federated instrument network and data archive for aerosol characterization, Rem. Sens. Environ., 66, 1-16, 1998.

Holtslag, A., de Bruijn, E., and Pan, H.-L.: A high resolution air mass transformation model for short-range weather forecasting, Mon. Wea. Rev., 118, 1561-1575, 1990.

Hsu, S.-A.: Thermodynamic characteristics of the subcloud layer affecting haze dispersion along the West coast of Borneo., Pure Appl. Geophys., 160, 419-427, 2003.

Hess, M., Koepke, P., and Shult, I.: Optical Properties of Aerosols and Clouds: The Software 15 Package OPAC, Bull. Am. Soc., 79, 831-844, 1998.

Jenkins, G. S.: The 1988 and 1990 summer season simulations for West Africa using a regional climate model, J. Climate, 10, 1255-1272, 1997.

Joussaume, S.: Three-dimensional simulation of the atmospheric cycle of desert dust particles using a general circulation model, J. Geophys. Res., 95, 1909-1941, 1990.

Kiehl, J., Hack, J., Bonan, G., Boville, B., Breigleb, B., Williamson, D., and Rasch, P.: Descrip-Description of the NCAR community climate model (ccm3), Technical report, National Center for Atmos. Res., 1996.

Lelieveld, J., Berresheim, H., Borrmann, S., Crutzen, P. J., Dentener, F. J., Fischer, H., et al.: Global air pollution crossroads over the Mediterranean, Science, 298, 794-799, 2002.

Liousse, C., Penner, J. E., Chuang, C., Walton, J. J., Eddleman, H., and Cachier, H.: A global three-dimensional model study of carbonaceous aerosols, J. Geophys. Res.-Atmos., 101, 19411$19432,1996$.

Luo, C., Mahowald, N., and del Corral, J.: Sensitivity study of meteorological parameters on mineral aerosol mobilization, transport and distribution, J. Geophys. Res., 108(D15), 4447, doi:10.1029/2003JD0003483, 2003. 
Mahowald, N., Zender, C., Luo, C., Savoie, D., Torres, O., and del Corral, J.: Under- Understanding the 30-year Barbados desert dust record, J. Geophys. Res., 107(D21), doi:10.1029/2002JD002097, 2002.

Marticorena, B. and Bergametti, G.: Modeling the atmospheric dust cycle, I, Design of soil- soilderived dust emission scheme, J. Geophys. Res., 100, 16416-16 430, 1995.

Marticorena, B., Bergametti, G., Gillette, D. A., and Belnap, J.: Factors controlling threshold friction velocity in semiarid areas of the United States, J. Geophys. Res., 102, 23 277-23 287, $1997 b$.

Marticorena, B., Bergametti, G., Aumont, B., Callot, Y., N'Doume, C., and Legrand, M.: Modeling the atmospheric dust cycle, 2, Simulation of Saharan sources, J. Geophys. Res., 102, 43874404, 1997a.

Martonchik, J. V., Diner, D. J., Kahn, R., Ackerman, T. P., Verstraete, M. M., Pinty, B., and Gorbon, H. R.: Techniques for the retrieval of aerosol properties over land and ocean using multiangle imaging, IEEE Trans. Geosci. Remote Sens., 36, 1212-1227, 1998.

Miller, R. L., Tegen, I., and Perlwitz, J.: Surface radiative forcing by soil dust aerosols and the hydrologic cycle, J. Geophys. Res., 109, D04203, doi:10.1029/2003JD004085, 2004.

Miller, R. L., Cakmur, R. V., Perlwitz, J., Geogdzhayev, I. V., Ginoux, P., Kohfeld, K. E., Koch, D., Prigent, C., Ruedy, R., Schmidt, G. A., and Tegen, I.: Mineral dust aerosols in the NASA Goddard Institute for Space Sciences ModelE atmospheric general circulation model, J. Geophys. Res., 111, D06208, doi:10.1029/2005JD005796, 2006.

Moulin, C., Lambert, C. F., Dulac, F., and Dayan, U.: Control of atmospheric export of dust from North Africa by the North Atlantic oscillation, Nature, 387, 691-694, 1997.

Myhre, G., Grini, A., Haywood, J. M., Stordal, F., Chatenet, B., Tanré, D., Sundet, J. K., and Isaksen, I. S. A.: Modeling the radiative impact of mineral dust during the Saharan Dust Experiment (SHADE) campaign, J. Geophys. Res., 108(D18), 8579, doi:10.1029/2002JD002566, 2003.

Nickovic, S., Kallos, S., Papadopoulos, A., and Kakaliagou, O.: A model for prediction of desert 25 dust cycle in the atmosphere, J. Geophys. Res., 106, 18 113-18 129, 2001.

Penner, J. E., Andreae, M., Annegarn, M., et al.: Aerosol, their direct and indirect effets, in: Climate Change 2001: The Scientific Basis. Contribution of Working Group I to the Third AsAssessment Report of the Intergovernmental Panel on Climate Change, edited by: Houghton, J. T., Ding, Y., Griggs, D. J., et al., Cambridge Univ. Press, New York, chap. 5, 291-336, 2001.
Qian, Y., Giorgi, F., Huang, Y., Chameides, W. L., and Luo, C.: Simulation of anthropogenic sulfur over East Asia with a regional coupled chemistry-climate model, Tellus B, 53B, 171191, 2001.

Rao, S. T., Ku, J.-Y., Berman, S., Zhang, K., and Mao, H.: Summertime characteristics of the atmospheric boundary layer and relationships to ozone levels over the Eastern United States, Pure Appl. Geophys., 160, 21-55, 2003.

Sokolik, I. N., Toon, O. B., and Bergstrom, R. W.: Modelling the radiative characteristics of air- airborne mineral aerosols at infrared wavelengths, J. Geophys. Res., 103, 8813-8826, 1998.

Solmon, F., Giorgi, F., and Liousse, C.: Aerosol modeling for regional climate studies: Appli- Application to anthropogenic particles and evaluation over a European/African domain, Tellus B, 58(1), 51-72, 2006.

Song, C. H. and Carmichael, G. R.: A three-dimensional modeling investigation of the evolution processes of dust and sea-salt particles in east Asia, J. Geophys. Res., 106, 18 131-18 154, 2001.

Schulz, M., Balkanski, Y., Guelle, W., and Dulac, F.: Role of aerosol size distribution and source location in a three dimensional simulation of a Saharan dust episode tested against satellite-derived measurements , J. Geophys. Res., 103, 10579 $10592,1998$.

Tanré, D., Remer, L. A., Kaufman, Y. J., Mattoo, S., Hobbs, P. V., Livingston, J. M., Russell, P. B., and Smirnov, A.: Retrieval of aerosol optical thickness and size distribution over ocean from 20 the MODIS airborne simulator during TARFOX, J. Geophys. Res., 104, 2261-2278, 1999.

Torres O., Bhartia, P. K., Herman, J. R., and Ahmed, Z.: Derivation of aerosol properties from satellite measurements of backscattered ultraviolet radiation. Theortical Basis, J. Geophys. Res., 103, 17 099-17 110, 1998.

Zender, C. S., Bian, H., and Newman, D.: Mineral dust entrainment and deposition 25 (DEAD) model: Description and 1990s dust climatology, J. Geophys. Res., 108, 4416, doi:10.1029/2002JD002775, 2003.

Zender, C. S., Miller, R. L., and Tegen, I.: Quantifying mineral dust mass budgets: Terminology, constraints, and current estimates, Eos Trans. Am. Geophys. Union, 85, 48, 509-512, 2004.

Zhang, L., Gong, S., Padro, J., and Barrie, L.: A size-segregated particle dry deposition scheme 30 for an atmospheric aerosol module, Atmos. Environ., 35, 549-560, 2001.

Zobler, L. A.: World Soil File for Global Climate Modelling, NASA Technical Memorandum 87802, NASA Goddard Institute for Space Studies (GISS), 2880 Broadway, New York, N.Y. 10025, USA, 1986. 